\title{
FISIOLOGIA E FARMACOLOGIA DOS MÜSCULOS DE MYTILUS PERNA
}

\section{Leila Abbud}

(*) Departamento de Fisiologia Geral e Animal da Faculdade de Filosofia, Ciências e Letras da Universidade de São Paulo e Instituto de Biologia Marinha da Universidade de São Paulo

38 Figs.

\section{N D I C E}

1. Introdução $\ldots \ldots \ldots \ldots \ldots \ldots \ldots \ldots \ldots \ldots \ldots, 116$

2. Material - Coleta e manutenção no laboratório . 118

3. Musculatura de Mytilus perna .............. 122

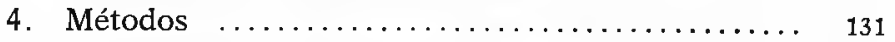

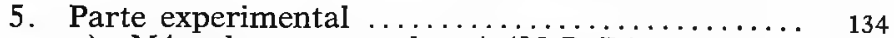

a) Músculo retrator do pé (M. R. P.) $\ldots \ldots \ldots \ldots .1 .34$

b) Músculo retrator anterior do bisso

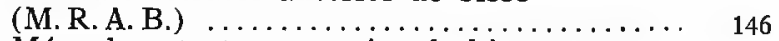

c) Músculo retrator posterior do bisso

(M. R. P. B.) $\ldots \ldots \ldots \ldots \ldots \ldots \ldots \ldots \ldots \ldots \ldots \ldots \ldots$

6. Discussão ............................ 160

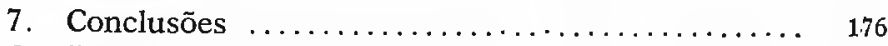

8. Bibliografia .......................... 178

RESUMO: Estudaram-se comparativamente a fisiologia e a farmacologia dos músculos retrator do pé (M.R.P.) e retratores anterior e posterior do bisso (M.R.A.B. e M.R.P.B.) de Mytilus perna e os correspondentes de $\mathbf{M}$. edulis. Preliminarmente, verificaram-se as diferenças anatômicas e topográficas. Registraram-se as reações dos músculos de M. perna às seguintes drogas: cloreto e brometo de Acetilcolina, cloreto e Acetil-betametilcolina (Mecolil), Nicotina, Fisostigmina, Prostigmina, cloreto de Succinilcolina, cloreto de d-Tubocurarina, triiodo-etilado de Galamina (Flaxedil), Benzoquinônio (Mitolon), sulfato de Atropina, di-hidrocloreto de Histamina, sulfato de Triptamina, 5-Hidroxi-triptamina (Serotonina), 1-Adrenalina, PiIocarpina e dietilamina do Acido Lisérgico (LSD). Como 
principal excitante empregou-se a $\mathrm{ACh}$, que provoca rápida contraçāo dos músculos, sendo lento o relaxamento dos M.R.A.B. e M.R.P.B. A Serotonina (5-HT) não age sôbre o M.R.P., mas sôbre os outros determina modificação nas respostas quando submetidos depois à $\mathrm{ACh}$, sendo então rápido o relaxamento. Pode-se dizer que o tratamento pela Serotonina faz com que o M.R.A.B. e M.R.P.B., sob a influência da $\mathrm{ACh}$, passem de músculos tônicos a músculos fásicos, tal como ocorre quando apenas estimulados pela corrente elétrica alternada.

\title{
PHISIOLOGY AND PHARMACOLOGY OF THE MUSCLES OF MYTILUS PERNA
}

\begin{abstract}
The retractor muscle of the foot (M.R.P.) and both retractors muscles of the byssus (M.R.A.B. and M.R.P.B.) of Mytilus perna and the corresponding to $\mathbf{M}$. edulis have been studied. Preliminary, the main anatomical differences of those muscles of both Lamellibranch were analysed. Reaction of those muscles of $\mathbf{M}$. perna were recorded after addition of the following drugs to the perfusion bath: Acetylcholine chloride and bromide, Acetyl-bethamethylcoline chloride; Nicotine, Physostigmine, Prostigmine, Succinylcholine chloride, d-Tubocurarine chloride, Gallamine tri-iodine ethylate, Benzoquinonium chloride (Mytolon), Atropine sulphate, Histamine dihydrochloride, Tryptamine sulphate, 5-Hydroxytryptamine-creatine sulphate (Serotonin), 1-Adrenaline, Pilocarpine and Lysergic Acid Diethylamide (L.S.D.) Acetylcholine chloride was the principal stimulator. All muscles contract rapidly by influence of this ester, but only M.R.A.B. and M.R.P.B. show slow relaxation. Serotonin (5-HT) does not act on the M.R.P. but on other muscles provokes different reaction when treated after by ACh. Instead of slow relaxation, the M.R.A.B. and M.R.P.B. in this case have rapid ones. This results allows to admit that Serotonin provokes the same effect of eletric A.C. stimulation on these muscles.
\end{abstract}

\section{CONCLUSIONS:}

1. Somatic muscles of $\mathbf{M}$. perna and $\mathbf{M}$. edulis differ anatomically. M. perna does not possess the anterior 
adductor muscle; the insertion of the M.R.P. on the inner face of the shell of $M$. perna is more anterior than in M. edulis. The M.R.A.B. are identic in both bivalves, but the M.R.P.B. possess in the inner surface of the shell only one zone of insertion in M. perna. Only this Bivalve has the median retractor muscle of the byssus.

2. Relaxation time of the M.R.A.B. and M.R.P.B. is prolonged after $\mathrm{ACh}$ stimulation.

3. The M.R.P., M.R.A.B. and M.R.P.B. do not react to Mytolon, Atropine, d-Tubocurarine and Flaxedil, but these drugs block the action of $\mathrm{ACh}$. Nicotine, after repeated stimulation is effective on the contraction of these muscles, depressing the contraction of the M.R.P. determined by ACh.

4. Only on the M.R.P. Succinylcholine potenciate ACh. This fact is discussed in the paper.

5. Serotonin (5-HT) does not excite the M.R.P. but in the beginning, acts as an inhibitor of ACh. On the M.R.A.B. and M.R.P.B. 5-HT provokes rapid relaxation of the muscles after contraction determined by $\mathrm{ACh}$.

6. The M.R.A.B. and M.R.P.B. are insensitive to Serotonin, but following addition of $\mathrm{ACh}$ those muscles show phasic instead of tonic contraction. 


\section{INTRODUÇÃO}

Os recentes progressos advindos do emprêgo da microscopia eletrônica e de outras técnicas modernas, se esclareceram muitos pontos controvertidos da fisiologia dos músculos estriados, não ampliaram substancialmente os conhecimentos sôbre os músculos lisos, tanto de Vertebrados como de Invertebrados.

Segundo FISCHER (1944, p. 467) os músculos lisos não podem ser considerados como uma unidade biológica. São músculos que podem apresentar propriedades fisiológicas diferentes, até num mesmo agrupamento de fibras musculares.

Ainda mais, no que tange aos Vertebrados, a musculatura lisa constitui, geralmente, parte integrante de um órgão, via de regra complicado na sua estrutura, ao passo que nos Invertebrados se encontram músculos lisos constituindo estruturas independentes, tal como as dos estriados. São na realidade, estruturas que se podem isolar e oferecem facilidade para as investigações fisiológicas tal como a musculatura estriada dos Vertebrados, reconhecidamente a mais bem estudada.

Interessada no estudo da fisiologia dos músculos lisos, especialmente dos Invertebrados marinhos, por sugestão do Prof. Dr. Paulo Sawaya, escolhi a musculatura dos Moluscos Lamelibrânquios para tentar esclarecer alguns aspectos dêstes músculos, que me pareceram mais importantes, cujos resultados talvez pudessem estender-se à fisiologia muscular em geral.

Como se sabe, muitos mexilhões vivem aderidos às rochas nas zonas expostas ao impacto das ondas do mar. Esse 
impacto, por vêzes extremamente violento, principalmente por ocasião das grandes tempestades, exige que os mexilhões disponham de meios adequados para poderem permanecer acolados às pedras. Das estruturas que concorrem para essa per. manência, sem dúvida, os músculos que agora serão estudados são de grande valia e é dêles que pretendo ocupar-me.

A bibliografia compulsada informa que os músculos das Mytilidae vêem sendo investigados por muitos autores, dentre os quais destaco TWAROG $(1949$, p. 2) que os julga adequados para o estudo do tônus. Podem mesmo servir para aprofundado estudo da fisiologia da fibra muscular lisa (FLETCHER, 1937a, p. 236; TWAROG 1954, p. 141; CAMBRIDGE \& HOLGATE 1955, p. 22P e vários outros). Em geral, os estudos realizados com a musculatura dêsses mexilhões, referem-se a Mytilus edulis, e, particularmente com o emprêgo da excitação elétrica e registro oscilográfico. Em 1959, porém, surge um trabalho de CAMBRIDGE, HOLGATE \& SHARP (1959, p. 451) tendente a esclarecer o mecanismo contrátil do músculo retrator anterior do bisso de $\boldsymbol{M}$. edulis, em que as estimulações se fizeram também com drogas. Circunstâncias várias levaram-me a empregar a estimulação por meio de drogas. Como se verá mais adiante, os resultados a que cheguei, em comparação com os demais autores que se ocuparam dêste assunto, não são discordantes, e permitem uma análise do fenômeno interessante da contração muscular.

Além disso, FLETCHER (1937a, p. 234) sugere a existência de funções diferentes entre o músculo retrator do pé e o retrator anterior do bisso, o mais estudado até hoje, e os demais músculos que, no conjunto, formam a musculatura dos mexilhões.

Por outro lado, tais estudos até agora se restringiram à musculatura do Mytilus edulis, lamelibrânquio que não tem sido encontrado na área em que trabalho. $O$ mexilhão de maior abundância no litoral brasileiro é o Mytilus perna, o qual como adiante se verá apresenta algumas diferen- 
ças com o Mytilus edulis, pelo menos no que se refere à disposição dos músculos.

Como se vê pela bibliografia compulsada, os dados sôbre a fisiologia muscular das Mytilidae referem-se, embora incompletamente, à dos músculos retratores do bisso. Os demais músculos não foram ainda devidamente considerados, e, por isso julguei de importância e de interêsse seu estudo em especial, no intuito de contribuir para o esclarecimento de vários aspectos da fisiologia muscular dos Invertebrados, principalmente marinhos.

2.

\section{MATERIAL - COLETA E MANUTENÇÃO NO LABORATÓRIO}

O material com que trabalhei consta de mexilhões comumente encontrados no litoral de São Paulo, e determinados como Mytilus perna pelo Museu de Zoologia Comparada da Universidade de Harvard.

A ocorrência de Mytilus (Chloromya) perna (Linneu, 1758) já foi assinalada por F. L. MORRETES (1949, p. 12) no Rio de Janeiro, Santos, E. Paraná, S. Francisco e Santa Catarina. Estudos recentes de KLAPPENBACH (1965, p. 335) informam ser Perna perna a espécie mais comum no Atlântico Sul.

Os animais foram coletados periòdicamente na baía de Santos, aderentes às rochas, nos arredores da Ilha de Urubuqueçaba (23⒋ $7^{\prime} 8^{\prime \prime} \mathrm{S}$; $46^{\circ} 22^{\prime} 25^{\prime \prime}$ 'W) transportados para São Paulo, e mantidos em aquários de água salgada, em circuito fechado no laboratório do Departamento de Fisiologia Geral e Animal. Sòmente durante os dez primeiros dias usei para as experiências fisiológicas os Mytilus existentes nos aquários. Além dêsse tempo, o material era destinado aos estudos anatômicos e a observações do comportamento em diversas condições. Utilizei também Mytilus coletados no litoral de 


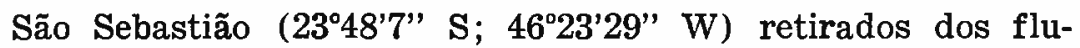
tuadores do porto e das rochas da práia de Toque-Toque Pequeno, a $10 \mathrm{~km}$ ao sul da cidade de São Sebastião. Êstes Mytilus foram mantidos nos aquários do laboratório do Instituto de Biologia Marinha na práia do Segrêdo, com água salgada corrente.

Releva notar as diferenças entre estas localidades. $O$ biótopo da ilha de Urubuqueçaba é semelhante ao da práia de Toque-Toque Pequeno, isto é, rochas graníticas expostas ao mar. Todavia, as da ilha Urubuqueçaba se acham dentro da baía de Santos, ao passo que as de Toque-Toque Pequeno estão expostas ao mar aberto. Se estas, achando-se em zona desabrigada se encontram em contáto mais frequênte com fortes ondas, o mesmo acontece com as de Urubuqueçaba, pelo menos durante as épocas de ressaca. Já no que se refere aos flutuadores do porto de São Sebastião o impacto das ondas do mar é muito menos intenso, dado que as mesmas se acham em pleno canal de São Sebastião e, por isso, ao abrigo da ressaca, protegidas pela ilha de São Sebastião.

Foi-me ainda possível obter alguns exemplares de $\boldsymbol{M}$. edulis e de $\boldsymbol{M}$. galloprovincialis graças à gentileza do Prof. Pierre Lubet, então professor de Fisiologia Comparada da Universidade de Lyon (França), que a convite do Instituto de Biologia Marinha da Universidade de São Paulo, estagiou em São Paulo como Professor Visitante, com a incumbência de orientar alguns trabalhos do «Programa Mytilus», programa êste votado ao estudo de múltiplos aspectos da biologia dêsses mexilhões sob a direção do Prof. Dr. Paulo Sawaya. Com êste material conseguí comparar a musculatura dêstes Mytilus.

Não desejando entrar no problema das formas de concha das Mytilidae relacionadas com o biótopo, julgo importante assinalar que as valvas de $\boldsymbol{M}$. perna coletadas no flutuador do Porto de São Sebastião se assemelham as de $\boldsymbol{M}$. edulis colhidas em Tamaris (Mediterrâneo) região calma como o canal de São Sebastião. Já os exemplares de $\boldsymbol{M}$. perna 
coletados nas rochas da práia do Toque-Toque Pequeno e da Ilha de Urubuqueçaba se mostram com o ângulo da margem dorsal muito menos acentuado (Fig. 1 e 2).

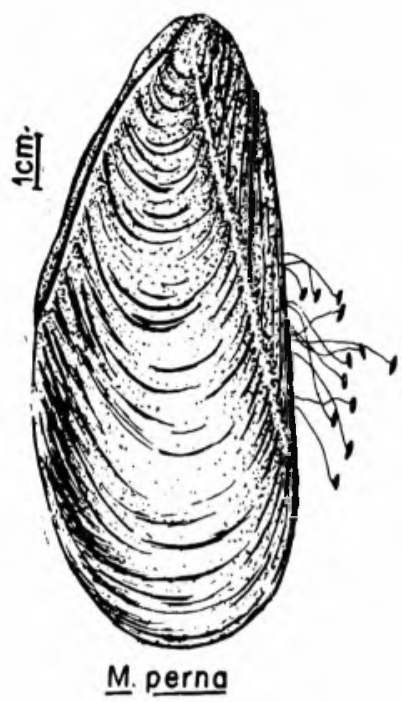

FIG. 1. Mytilus perna da Ilha de Urubuqueçaba

Colhidos os animais e transportados para o laboratório do Instituto de Biologia Marinha, ou para o laboratório do Departamento de Fisiologia Geral e Animal, foram abertos pela secção do músculo adutor, com o emprêgo de um bisturí introduzido entre as valvas, fazendo-se a operação cuidadosamente de modo a evitar lesão dos demais músculos. A seguir, os mexilhões eram abertos completamente, procedendose a retirada do músculo desejado.

Para o estudo anatômico de $\boldsymbol{M}$. perna e $\boldsymbol{M}$. edulis, usei animais fixados, inteiros, em formalina neutra a $4 \%$ e em Bouin-Hollande e Bouin;

Ainda para os estudos morfológicos trabalhei com alguns mexilhões que foram dissecados do seguinte modo: introduzi 
c bisturí entre as valvas, seccionando assim o músculo adutor porterior com o que cessava a resistência oferecida por êste músculo e, em consequência as valvas se abriam. A seguir coloquei o animal dentro de cubas com água do mar e separei ao máximo as valvas, tendo o cuidado de não romper o ligamento que as une. Dêste modo, obtive ampla exposição das partes moles que, então, puderam ser estudadas. Fiz a remoção delas e desta maneira os músculos que me interessavam ficaram bem expostos.

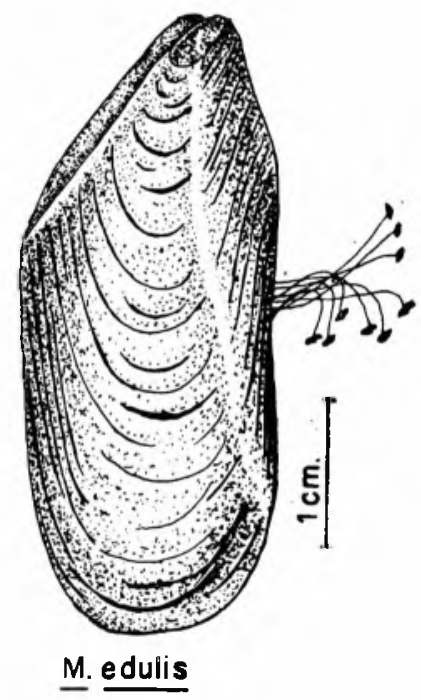

FIG. 2. Mytilus edulis

Para conseguir uma boa fixação do animal inteiro, tomei os Mytilus vivos e introduzi na região posterior entre as valvas, a lâmina de um bisturi. Assim, foi possível, com pequeno esfôrço provocar ligeira separação delas. Na pequena abertura, então, introduzi cunhas de cortiça que impediam o fechamento. A seguir o animal era mergulhado no fixador, que pela abertura, penetrava e fixava muito bem as partes moles do Mytilus. 
3.

\section{MUSCULATURA DE MYTILUS PERNA}

Com o objetivo principal de estudar a fisiologia da musculatura do Mytilus perna, primeiramente procurei identificar cada um dos músculos, tanto em material fresco ou fixado em formalina ou Bouin, de modo a estar segura de que material iria servir-me no presente estudo.

Desde logo, ao iniciar a pesquisa, notei que o mexilhão das nossas práias não possui a musculatura com a mesma disposição e número que a do Mytilus edulis, sem dúvida um dos lamelibrânquios melhor conhecidos nêste particular, como se depreende do trabalho clássico de WHITE (1937, p. 73).

A vista das discrepâncias encontradas, resolvi dedicarme imediatamente ao estudo comparativo da musculatura de ambas as espécies de Mytilus, o que me pareceu indispensavel: a) para registrar as diferenças existentes; b) para escolher os músculos adequados para as pesquisas fisiológicas.

A musculatura de $\boldsymbol{M}$. edulis e a de $\boldsymbol{M}$. perna diferem não sómente quanto à disposição de cada um dos músculos, quanto à própria conformação dêles.

Desde logo verifiquei, também, que a musculatura de $\boldsymbol{M}$. edulis é idêntica a de $\boldsymbol{M}$. galloprovincialis, mas bem distinta da de $M$. perna.

Como se sabe, a maioria dos autores trabalhou com M. edulis ao estudar a fisiologia ou a farmacologia dos músculos, utilizando de preferência o músculo retrator anterior do bisso ou os músculos adutores, anterior e posterior, intátos ou isolados, em câmaras perfusôras uu em aparelhos especiais.

Chama a atenção o fato de EGGLETON (1934, p. 79) e de GLAISTER \& KERLY (1936, p. 56) ao trabalharem com êstes músculos indicarem o músculo retrator do pé, quando, ao que parece, o músculo retrator anterior do bisso é que 
usaram, conforme apontam FLETCHER (1937a, p. 234), e TWAROG (1949, p. 43).

O mesmo engano já havia sido cometido por BOUTAN $(1900$, p. 464). Além disso, êste autor menciona os músculos retratores posteriores do pé com um ou dois feixes, em M. edulis. Pelo menos os exemplares que tive à disposição não mostraram estas estruturas, mas apresentam um único par de pequenos músculos arredondados, inserindo-se na face interna dorsal, logo abaixo da linha mediana transversal do animal.

Parece assim justificada a conveniência e a necessidade de comparação entre o nosso mexilhão e o $\boldsymbol{M}$. edulis, pelı menos no que se refere à musculatura.

Sendo o objetivo principal do presente trabalho o estudo da fisiologia e da farmocologia dos músculos de $M$. perna neste capítulo farei a descrição sumária de cada um dêstes músculos, procurando sempre que possível e oportuno fazer a comparação com a musculatura correspondente de $\boldsymbol{M}$. edulis.

A falta de material mais abundante e adequado dêste último levou-me a limitar a descrição aos músculos de $\boldsymbol{M}$. perna reservando para outra oportunidade estudo comparativo mais aprofundado das estruturas, principalmente a muscular, destas duas espécies de mexilhões.

A musculatura de $\boldsymbol{M}$. perna e de $\boldsymbol{M}$. edulis consta dos seguintes músculos: a) Adutores; b) Bissais e c) Pedais.

A) MŨSCULOS ADUTORES (Fig. 3-6 M.A.A. e M.A.P.) - Em M. perna existe apenas o adutor posterior, e em $M$. edulis, ocorre também o adutor anterior (Fig. 5 e 6 , M.A.P. e M.A.A.). O músculo adutor posterior (Fig. 3 e 4, M.A.P.) é bem desenvolvido em ambos os mexilhões, sendo de forma ovalada, visto em secção transversal em $\boldsymbol{M}$. edulis, e ovalada-arredondada em $\boldsymbol{M}$. perna. Inserem-se na face profunda de cada uma das valvas, muito próximo do 
pólo posterior, à cêrca de $1 \mathrm{~cm}$ da borda dorsal. As impressões deixadas na face profunda da valva, mostram bem a forma dêste músculo (Fig. 4, 5 e 6, M.A.P.). E nítida a forma ovalada de contornos irregulares. O maior diâmetro mede, em média $\mathrm{cm} 1,5$ e o menor $1 \mathrm{~cm}$, nos exemplares adultos. A borda anterior do músculo é contígua com a posterior do músculo retrator posterior do bisso. Êste é um músculo espêsso, longo, com $3 \mathrm{cms}$ de extensão, muito potente. A Fig. 6, M.A.P., mostra o aspecto da inserção dêste músculo na face profunda da valva de $\boldsymbol{M}$. edulis. Nota-se $\circ$ aspecto aproximadamente prismático do músculo. Nêste mexilhão o m. adutor posterior, em geral, não é contíguo com o $\mathrm{m}$. retrator posterior do bisso.

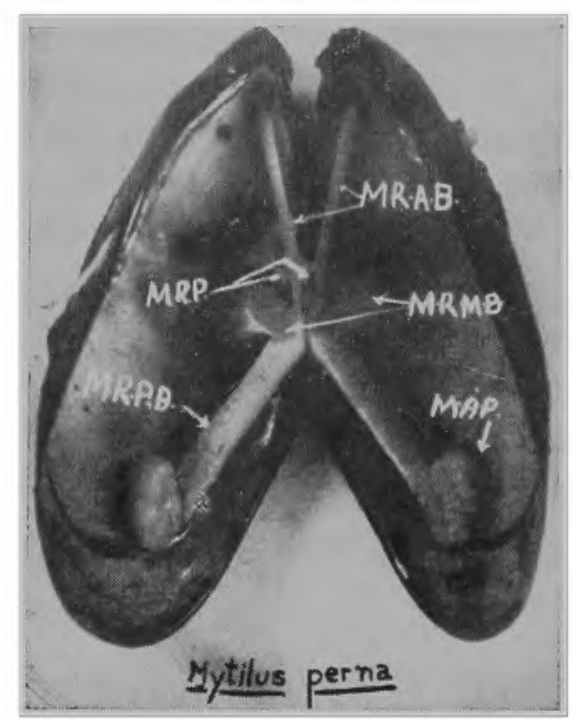

FIG. 3. Mytilus perna, dissecado para estudo da musculatura. M.A.P. = músculo adutor posterior; M.R.P. = músculo retrator do pé; M.R.A.B. = músculo retrator anterior do bisso; M.R.M.B. $=$ músculo retrator mediano do bisso; M.R.P.B. = músculo retrator posterior do bisso.

Como foi dito acima, no M. edulis há também o músculo adutor anterior (Fig. 6, M.A.A.) muito pequeno, fino, com 


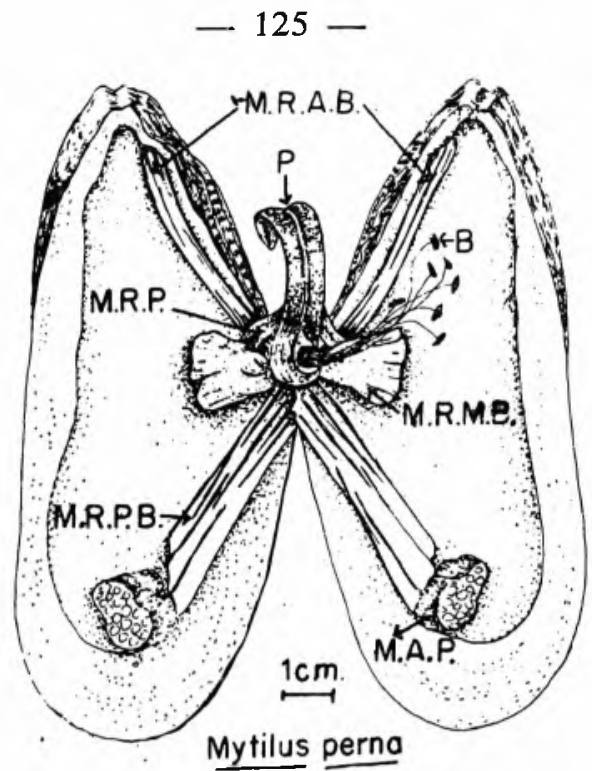

FIG. 4. Mytilus perna. Esquema dos músculos. M.A.P. = músculo adutor posterior; M.R.P. = músculo retrator do pé; M.R.A.B. = músculo retrator anterior do bisso; M.R.M.B. $=$ músculo retrator mediano do bisso; M.R.P.B. = músculo retrator posterior do bisso; $\mathbf{B}=$ bisso; $\mathbf{P}=$ pé.

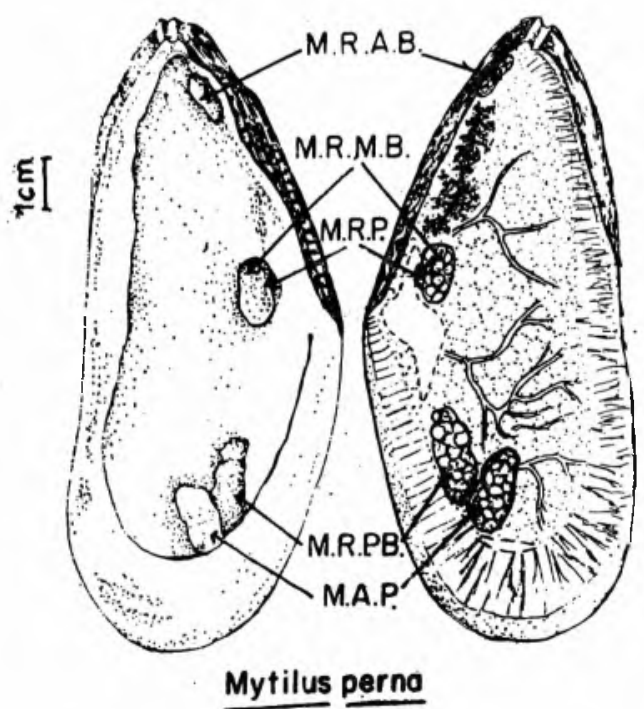

FIG. 5. Esquema de Mytllus perna dissecado mostrando as impressões dos músculos na valva direita. $\mathrm{Na}$ esquerda estão desenhadas as partes moles. M.A.P. = músculo adutor posterior; M.R.P. = músculo retrator do pé; M.R.A.B. = músculo retrator anterior do bisso; M.R.M.B. = músculo retrator mediano do bisso; M.R.P.B. = músculo retrator posterior do bisso. 
inserção na face profunda das válvas, junto ao polo anterior, e colado na margem ventral. A impressão que deixa na superfície profunda da valva (Fig. $6-$ M.A.A.) indica bem o pequeno desenvolvimento dêste músculo.

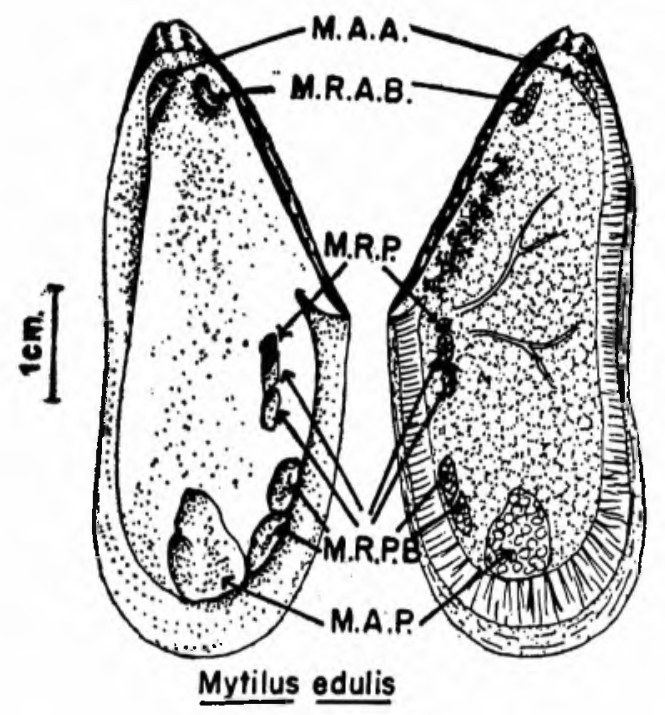

FIG. 6. Esquema de Mytilus edulis dissecado. Na valva esquerda, encontram-se em esquema, as partes moles. M.A.P. = músculo adutor posterior; M.R.P. = músculo retrator do pé; M.R.A.B. = musculo retrator anterıor do bisso; M.R.M.B. = músculo retrator mediano do bisso; M.R.P.B. = músculo retrator posterior do bisso; M.A.A. = músculo adutor anterior.

B) MÚSCULOS DO BISSO (Fig. 3-6, M.R.A.B., M.R.P.B. e M.R.M.B.).

São músculos bem desenvolvidos tanto em $M$. perna como em M. edulis. O M.R.A.B. tem os pontos de inserção na face profunda da concha muito próximo ao polo anterior dorsal, e adjacente à borda da charneira. Nos exemplares adultos a impressão deixada na concha indica muito bem as dimensões dêste mủsculo, que são, em $\boldsymbol{M}$. perna, de forma alongada, de maior eixo paralelo à borda dorsal da concha, à qual é adjacente e, em $\boldsymbol{M}$. edulis, também alongada, mas 
menos evidente, talvez por serem os músculos menos potentes, separados da borda da concha, mas de maior eixo também a ela paralelo. Dêstes pontos de inserção os dois M.R.A.B. se dirigem para o pólo posterior, convergindo ambos para $\circ$ centro do animal (Fig. 3 e 4, M.R.A.B.). Abaixo da região cardíaca ambos se fundem, juntando-se aos M.R.P.B. Entre êstes músculos (Fig. 10, M.R.A.B., M.R.M.B. e M.R.P.B.) intercala-se o M.R.M.B. Êste último músculo Fig. 3, 4 e 10, M.R.M.B.) é muito curto, insere-se dorsalmente na face profunda das valvas, num ponto próximo ao ângulo formado pela borda dorsal da concha (Fig. 5, M.R.M.B.). São dois músculos que convergem para a região central mediana e aí se encontram com os retratores anterior e posterior do bisso. Em geral, os autores que estudaram os Mytilus (WHITE l. c., p. 78) omitem êste músculo que é muito evidente em M. perna e o incluem entre o M.R.P.B., pois se inserem na região dorsal posterior interna da concha.

Já o músculo retrator posterior do bisso, em ambos os mexilhões, se dispõem na região próxima ao pólo posterior imediatamente adeante do músculo adutor posterior, com '] qual, como disse, é contíguo. São duas massas musculares fortes, que se inserem posteriormente no ponto já indicado (Fig. 3-6, M.R.P.B.) e daí se dirigem para adeante, oblíquamente, em direção à margem dorsal das valvas, convergindo ambos os músculos para a região onde se encontra o bisso na qual ambos tem origem (Fig. 7 e 9, M.R.P.B.). No M. edulis (Fig. 6, M.R.P.B.) mostra-se mais fraco, deixando pequenas impressões no seu ponto de inserção, na face profunda das valvas, daí se dirigem para a região anterior, convergindo para a região mediana, indo, no ponto proximn ao ângulo da margem dorsal, fundir-se com o par de músculos retratores anteriores do bisso. Também em $\boldsymbol{M}$. perna ocorre êsse mesmo aspecto, apenas os músculos são mais robustos e não se subdividem próximos à inserção (Fig. 3-5, M.R.P.B), como se pode notar pela diferença das dimensões das impressões deixadas na face interna das valvas. 


\section{C) MÚSCULOS DO PE (Fig. 3 a 10, M.R.P.)}

Um par de músculos pequenos, finos, que se insere na. face profunda da concha onde deixa uma impressão diminuta contígua a do músculo retrator mediano do bisso (Fig. 5, M.R.P., M.R.M.B.) na sua borda dorsal, isolada no M. edulis (Fig. 6, M.R.P.), constituindo sua inserção na face profunda da concha a impressão mais próxima do ângulo da margem dorsal. Êste músculo acha-se aderente ao músculo retrator mediano do bisso em M. perna (Fig. 7, M.R.P.) e se apresenta isolado em M. edulis (Fig. 8, M.R.P). No primeiro dêstes dois mexilhões tal músculo é mais robusto e de sua inserção, na face profunda (Fig. 10, M.R.P) da concha, dorsalmente ao M.R.M.B, se dirige para o pólo anterior, ventral, ultrapassando externamente o M.R.A.B. indo formar com outras fibras musculares e demais tecidos o pé do Mytilus.

Convém destacar serem os músculos do pé dêsses mexilhões independentes dos músculos do bisso.

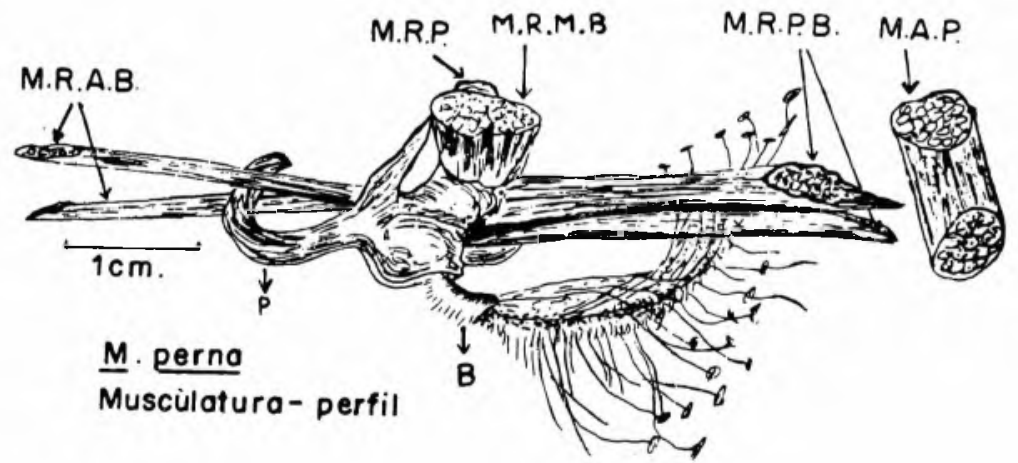

FIG. 7. Esquema dos músculos do M. perna. Vista de perfil. M.A.P. = m. adutor posterior; M.R.P. = m. retrator do pé; M.R.A.B. = m. retrator anterior do bisso; M.R.M.B. = m. retrator mediano do bisso; M.R.P.B. = m. retrator posterior do bisso; $\mathrm{B}=$ bisso; $\mathrm{P}=$ pé.

Como se vê, há sensíveis diferenças na forma, na disposição e no desenvolvimento dos músculos de $\boldsymbol{M}$. perna e de $\boldsymbol{M}$. edulis. Após êste estudo pude bem distinguir os principais músculos 
que constituem objeto de investigação sob o ponto de vista fisiológico e farmacológico.

Deixei de parte uma inquirição mais minuciosa sôbre o complexo muscular resultante da reunião das extremidades livres dêstes músculos, do qual emerge não sómente o pé como a. glândula do bisso destas Mytilidae.

Individualisados os músculos, foi então possível, dissecar cuidadosamente para cada experiência o músculo retrator do pé, o músculo retrator anterior do bisso e o músculo retrator posterior do bisso. Não me foi possível, cumpre-me declarar, trabalhar com o músculo retrator mediano do bisso por ser muito curto e de difícil manuseio mesmo após a dissecção. Do mesmo modo, deixei de parte, o músculo adutor posterior.

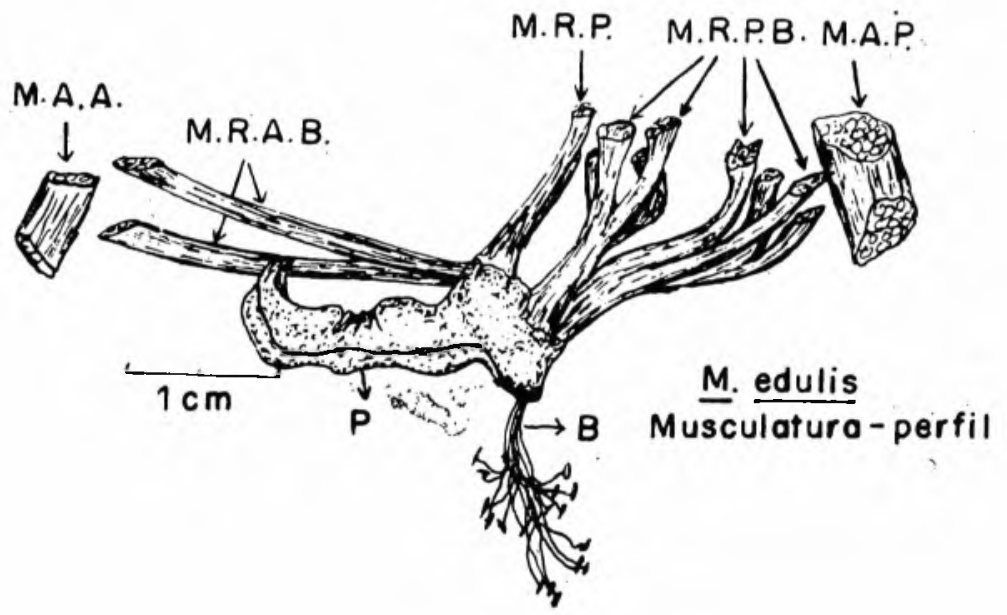

FIG. 8. Esquema da musculatura de M. edulis. Vista lateral. M.A.P. = m. adutor posterior; M.R.P. = m. retrator do pé; M.R.A.B. = m. retrator anterior do bisso; M.R.P.B. = m. retrator posterior do bisso; $\mathbf{B}=$ bisso; $\mathbf{P}=$ pé; $\mathbf{M}$.A.A. = músculo adutor anterior.

Devo acentuar que os autores que se ocuparam com 0 estudo dêstes músculos em $\boldsymbol{M}$. edulis omitem o retrator mediano do bisso e mesmo consideram as fibras, que correspon- 
deriam talvez a êste músculo, como pertencendo ao músculo retrator posterior do bisso (Fig. 6, M.R.P.B.).

Além disso, não houve oportunidade de estudar com mais pormenores as origens dêstes músculos tanto no pé como no bisso, visto como, para o objetivo principal dêste trabalho pràticamente, não precisariam ser consideradas.

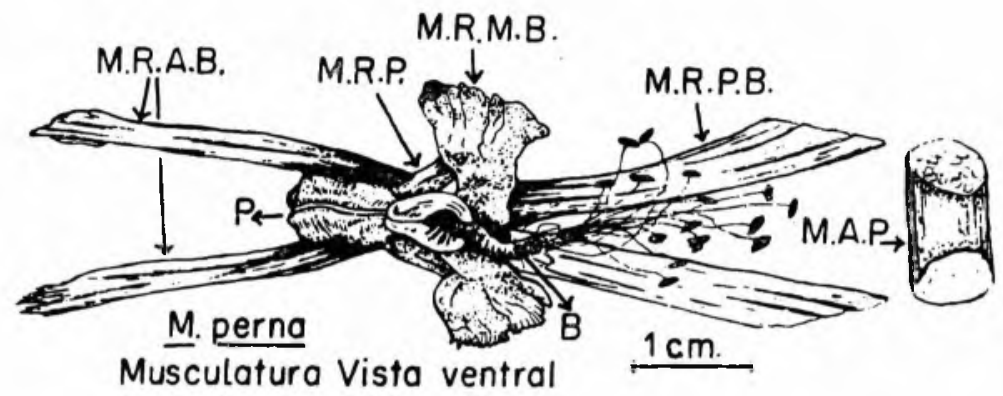

FIG. 9. Esquema da musculatura de M. perna. Vista ventral. M.A.P. = m. adutor posterior; M.R.P. = m. retrator do pé; M.R.A.B. = m. retrator anterior do bisso; M.R.M.B. = m. retrator mediano do bisso; M.R.P.B. = m. retrator posterior do bisso; $\mathbf{B}=$ bisso; $\mathbf{P}=$ pé.

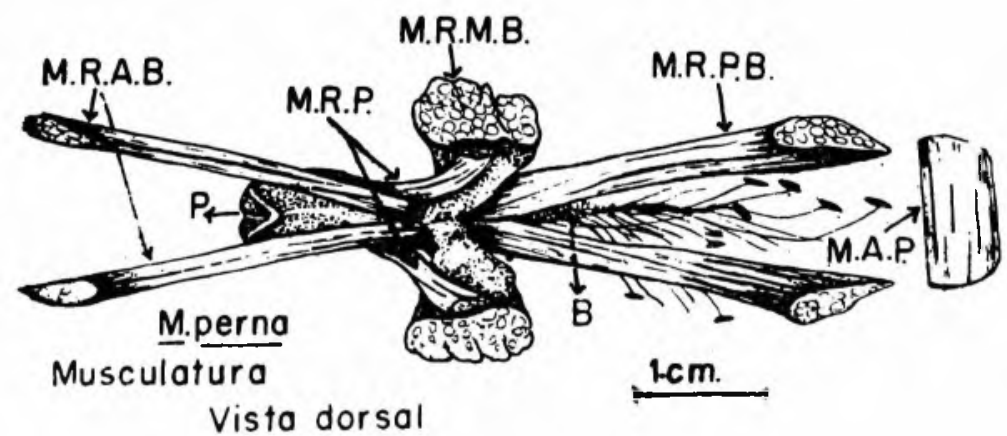

FIG. 10. Esquema da musculatura de M. perna. Aspecto dorsal. M.A.P. $=\mathrm{m}$. adutor posterior; M.R.P. $=\mathrm{m}$. retrator do pé; M.R.A.B. $=\mathrm{m}$. retrator anterior do bisso; M.R.M.B. = m. retrator mediano do bisso; M.R.P.B. = m. retrator posterior do bisso; $\mathrm{B}=$ bisso; $\mathbf{P}=$ pé. 
4.

\section{METODOS}

Nas preparações para as experiências fisiológicas e farmacológicas utilizou-se a mesma técnica de dissecção já descrita para estudos anatômicos. Apenas se cuidou melhor de proteger a integridade das fibras musculares, ou seja, os animais, no momento da dissecção eram colocados em cubas com água do mar filtrada e então lavados. Como se sabe, os mexilhões são isosmóticos em relação à água do mar (FLORKIN \& HAROLD 1934, p. 353). O objetivo dêsse proceder foi o de evitar contaminação das preparações, por produtos sexuais, enzimas do estilete cristalino ou secreções da glândula do intestino médio.

Dissecados, os músculos eram amarrados nas duas extremidades ou fixos em pequenos discos recortados na região de sua inserção na concha e sòmente a outra extremidade ligada por um fio de linha fina à alavanca inscritora. Assim, os músculos isolados intactos permitiam o uso dessa técnica introduzida por HOYLE \& LOWY (1956, p. 297) para M.R.A.B. Éstes autores, porém, utilizaram também músculos seccionados ao nível das duas extremidades, não observando variação nos resultados obtidos com uma ou outra preparação.

Confirmando as observações de HOYLE \& LOWY (l.c.), logo nas primeiras preparações usadas, com discos de concha numa das extremidades ou ambas cortadas, resolvi libertá-las totalmente da concha, pois utilizando animais grandes (de 8 a $12 \mathrm{~cm}$ medidos no eixo antero-posterior), a resistência das valvas ao recorte dos discos era enorme, dificultando o preparo da peça, muitas vêzes lesando algumas fibras musculares, por fratura da concha na zona de inserção muscular.

No caso do M.R.P., o setor usado é o compreendido entre o ponto de inserção dêste par de músculos na concha até a região em que se unem para formar a massa do pé pròpriamente dito. Este cuidado foi tomado a fim de se evitar re- 
gistro da ação de outras unidades musculares que também se acham presentes, nessa estrutura, sem fazer parte do M.R.P. Após a dissecção do animal, os músculos retratores do bisso eram afastados, deixando na concha apenas o par de M.R.P. Êstes eram amarrados com alça de linha próximo à inserção e com fio de linha comprido próximo à base do pé, porção esta que era excisada. Com a ponta do bisturí, deslocava agora a outra extremidade do músculo, junto à sua inserção na concha, e a preparação estava pronta para ser usada.

$\mathrm{O}$ músculo isolado e recém dissecado, medindo de $\mathrm{cm}$ 1,0-1,5 de comprimento, era colocado em placas de petri com água do mar filtrada durante 10 minutos, até sua montagem no banho perfusor. Nêsse ínterim tinha início o relaxamento.

Para trabalhar com o M.R.A.B. ou M.R.P.B. bastava cortar o M.A.P. com bisturí, abrir o animal, rebater até a região mediana a porção anterior do manto e vísceras, para isolar o M.R.A.B., e a porção posterior do manto e vísceras para separar o M.R.P.B. Os tecidos eram retirados da concha com auxílio de bisturí e trazidos para o centro por meio de pinça, deixando livres os M.R.A.B., e os M.R.P.B., que eram então amarrados com fio de linha comprido na zona de confluência dos músculos com a glândula do bisso e com a. alça de linha próximo à zona de inserção. Junto à glândula do bisso, os músculos eram cortados com tesoura fina e na zona de inserção sempre foram dissecados com bisturí como descrito acima para o M.R.P.

O segmento amarrado do M.R.A.B. após excisão, media de cm 0,7 a 1,2 e o do M.R.P.B. de cm 0,5 a 1 .

Os músculos, assim preparados, eram montados no banho perfusor constituido de um tubo de vidro de $\mathrm{cm} 1,5$ de diâmetro e 15 de comprimento, obturado inferiormente por rôlha de borracha dotada de 3 vias de comunicação por meio de tubos, dois maiores servindo um dêles à introdução de água do mar filtrada proveniente de um frasco de Mariotti, passando por uma bureta graduada de $25 \mathrm{ml}$ o outro destinado ao esvaziamento do líquido perfusor; a terceira comunicação, 
dotada de ponta capilar em formato de gancho, voltada para o interior do banho, servindo ao mesmo tempo para o arejamento da preparação e também para prender a porção de inserção do músculo na concha. A outra extremidade do músculo é conectada com o ramo posterior da alavanca inscritôra, com um fio de linha.

Usando a alavanca frontal, tipo Schild, com longa ponta inscritôra, registraram-se contrações isotônicas num cilíndro móvel com papel esfumaçado, como respostas a drogas adicionadas a $10 \mathrm{ml}$ de banho (volume final) de água do mar filtrada, à temperatura ambiênte $\left(23^{\circ}\right.$ a $\left.26^{\circ} \mathrm{C}\right)$. Tôdas as drogas foram diluidas em água do mar filtrada, a partir de soluções estoques concentradas. As seguintes drogas foram usadas:

Cloreto de acetilcolina (Roche e Rhodia) ou brometo de acetilcolina (Eastman), cloreto de acetil-beta-metilcolina (mecolil, Nat. Biochm. Corp.), nicotina (Eastman), eserina (fisostigmina Merck), prostigmina (Merck), cloreto de succinilcolina (taquicurin, L.P.B.), cloreto de d-tubocurarina (Bios), flaxedil (Rhodia), mitolon (Sterling, Winthrop), sulfato de atropina (Merck \& B.D.H.), dihidrocloreto de histamina (Pfanstiehl), sulfato de triptamina (Sigma), serotonina (Sigma \& L. Light), l-adrenalina (Eastman), pilocarpina (Merck) e L.S.D. (Delysed, Sandoz Product Ltd. London).

Aproveito a ocasião para agradecer ao Dr. Paulo Sawaya, diretor do Departamento de Fisiologia Geral e Animal e do Instituto de Biologia Marinha da Universidade São Paulo pelo auxílio prestado durante a elaboração dêste trabalho, bem como pela orientação do mesmo; ao Dr. Erasmo G. Mendes, pelo apôio, interêsse e sugestões no decorrer dos experimentos; à Fundação para o Amparo à Pesquisa do Estado de São Paulo, pela bolsa concedida para iniciar os experimentos; ao Prof. Pierre Lubet pelos exemplares de $\boldsymbol{M}$. edulis e $\boldsymbol{M}$. galloprovincialis, trazidos da França. 
5.

\section{PARTE EXPERIMENTAL}

Fixos na parte inferior da câmara de perfusão cheia de água do mar filtrada e na alavanca inscritôra, os músculos M.R.P., M.R.A.B. e M.R.P.B., levavam cêrca de 15 a 30 minutos para relaxar, após o que mantinham o comprimento estável. Em nenhum dêles se observaram movimentos espontâneos, independentes do tratamento por drogas.

Durante as experiências foi possível manter a linha de base, achando-se o músculo totalmente relaxado. Após a administração de uma droga, ativa ou não, as preparações foram lavadas com o líquido perfusor, desligando-se o quimógrafo. No caso de uma substância que provocava contração, efetuava-se a lavagem do músculo iniciando-se imediatamente o relaxamento, no caso do M.R.P. ou mantendo o nível de contração durante muito tempo, como adiante se verá, no caso do M.R.A.B. e do M.R.P.B.

A seguir passarei a relatar as experiências efetuadas com os referidos músculos, submetendo-os a uma série de drogas, em geral de uso comum na farmacologia, na tentativa, como disse, de elucidar alguns aspectos da fisiologia destas estruturas.

\section{a) MUSCULO RETRATOR DO PĒ (M.R.P.)}

Diferentemente dos demais pesquisadores que se ocuparam principalmente do músculo retrator anterior ou do músculo retrator posterior do bisso, detive-me particularmente no estudo do músculo retrator do pé (M.R.P.), não só por não ter encontrado estudos a respeito do mesmo, como por ter verificado sensíveis diferenças funcionais relativamente aos demais músculos acima referidos.

1. Açâo da Acetilcolina - Os músculos empregados foram suspensos da maneira usual, em banho perfusor arejado 
e as soluções das drogas usadas em décimos de ml adicionadas ao banho para perfazer o total de $10 \mathrm{ml}$ de líquido. Em consequência, as concentrações em uma certa diluição, foram expressas em miligramas ou microgramas da droga, em $10 \mathrm{ml}$ do fluido perfusor. O tempo de ação da droga foi de 30 e algumas vêzes de 60 segundos, com dois a três minutos de intervalo entre a lavagem da preparação e a experiência seguinte.

A Fig. 11 mostra respostas do músculo de comprimento de cêrca de $1 \mathrm{~cm}$, medido logo após a excisão e de 2,5 no máximo do relaxamento, quando submetido à ação da $\mathrm{ACh}$ em concentrações crescentes de 0.1 a $6 \mu \mathrm{g}$. O limiar para a $\mathrm{ACh}$ acha-se ao redor de $10^{-8}$ ou seja $0.1 \mu \mathrm{g} \mathrm{em} 10 \mathrm{ml}$. A gama de doses para obtenção da curva de sensibilidade para esta droga foi de $1 \times 10^{-8}$ a $6 \times 10^{-7}$ (Fig. 11).

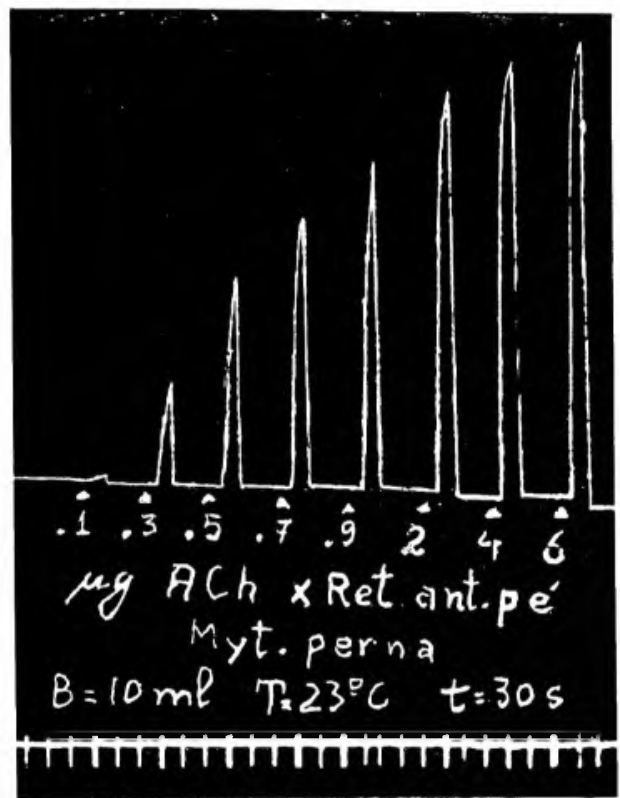

FIG. 11. Sensibilidade do M.R.P. à Acetilcolina. Curva dose-efeito.

As relações entre a concentração da droga e o efeito obtido (curva dose-efeito) acham-se demonstradas na Fig. 12. 
A relação entre a amplitude da contração medida em $\mathrm{mm}$ e as concentrações do éster, escolhidas numa progressão geométrica foram tratadas estatìsticamente. A seleção das doses fez-se dentre as que provocavam contrações pequenas até submáximas.

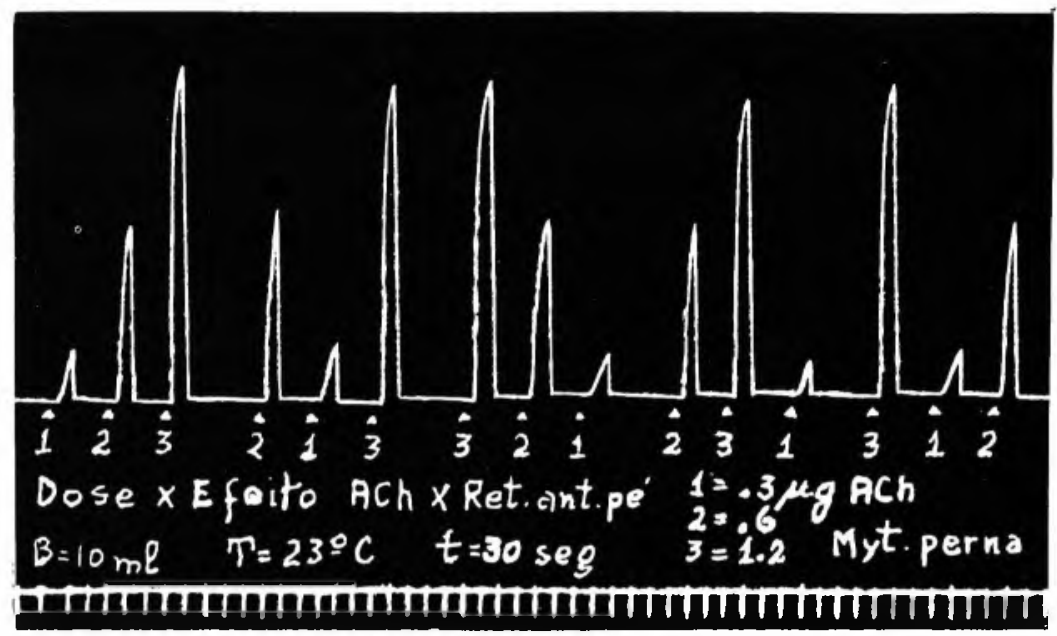

FIG. 12. Contrações do M.R.P. Dose-efeito.

Usei ao acaso três doses $(0.3,0.6$ e $1.2 \mu \mathrm{g})$, portanto, na razão de 1:2, em cinco grupos de três. O tratamento estatístico dos dados revelou que as respostas do músculo seguiram a linha reta, com a linha de regressão significante e desvio da linearidade não significante. A razão de variação entre grupos também foi insignificante, indicando variação não substancial da sensibilidade durante a experiência. O êrro padrão $\mathbf{S}=0,99$ representou cêrca de $5 \%$ da média para tôdas as determinações. A Tabela I e o gráfico da Fig. 13 mostram os dados obtidos nas experiências dose-efeito.

2. Potencialização da Acetilcolina - A Fig. 14 mostra a influência da Fisostigmina $(0.1 \mathrm{mg})$ que potencializou persistentemente a ação da ACh sobreposta na concentração final de $3 \times 10^{-\tau}$. A Prostigmina produz o mesmo efeito. 


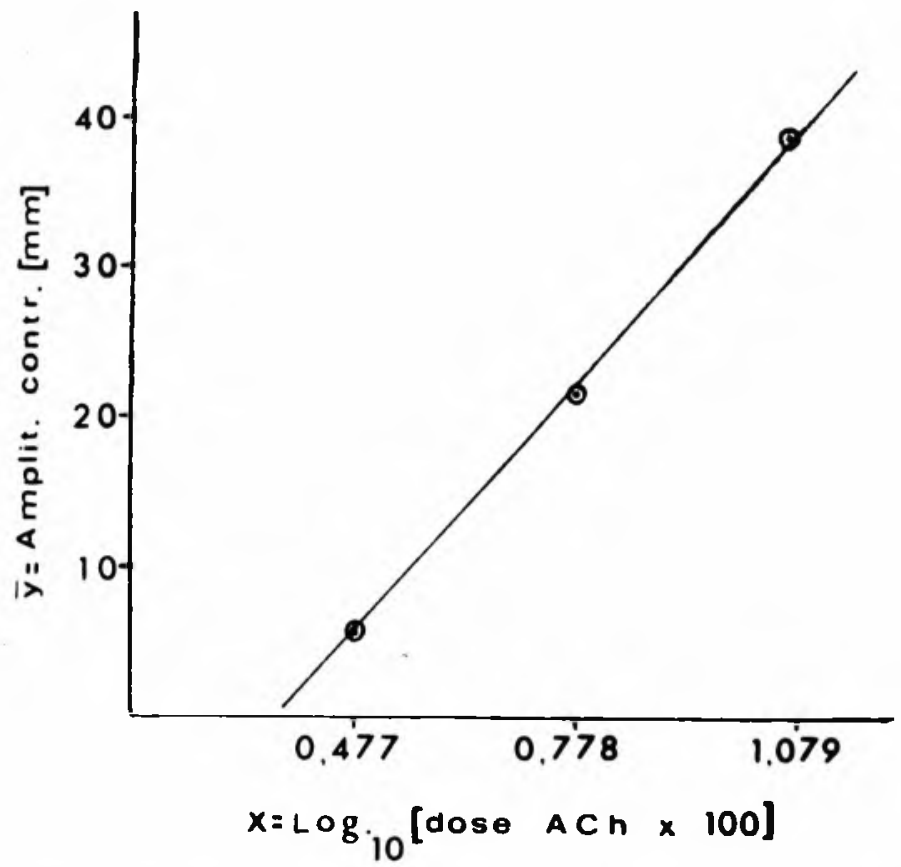

FIG. 13. Representaçāo gráfica dos dados da Tabela I.

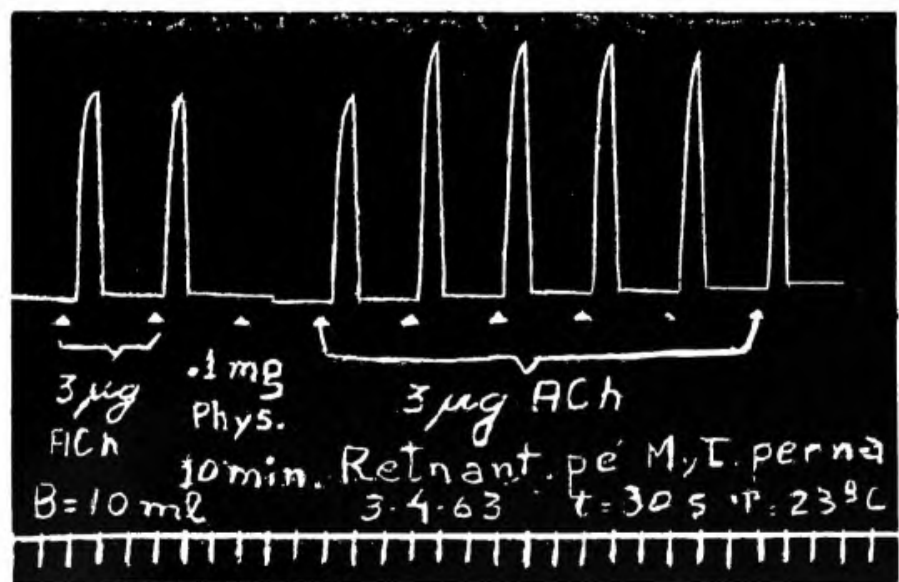

FIG. 14. Contraçōes do M.R.P. de M. perna. Potencializaçāo da ACh pela Fisostigmina. 
TABELA I

ANALISE ESTATISTICA DOS DADOS DA CURVA DOSE-EFEITO Acetilcolina x Músculo Retrator do pé de Mytilus perna

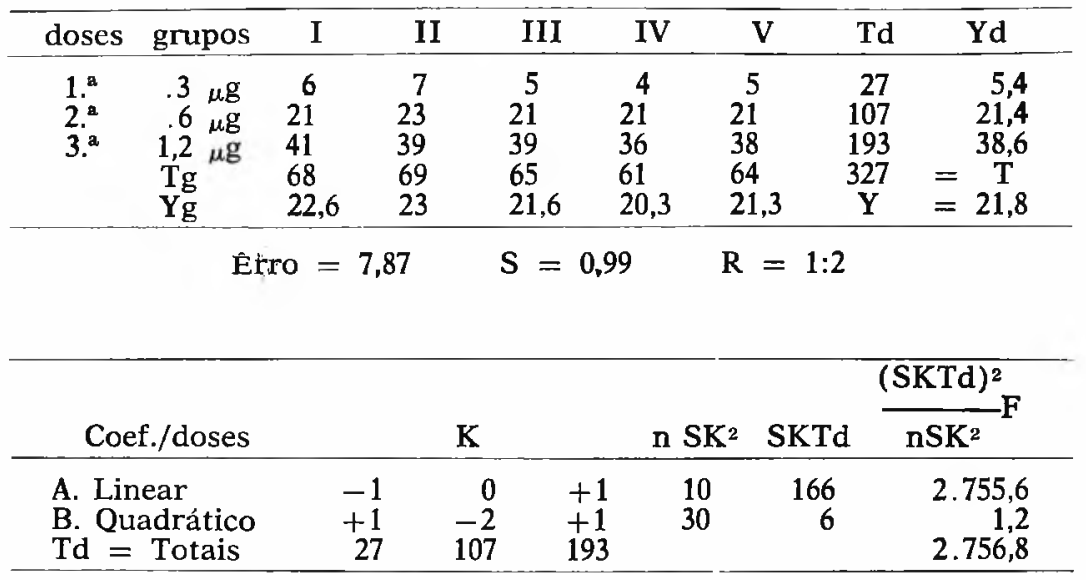

$*$

ANALISE DE VARIÂNCIA DOS DADOS DA TABELA

\begin{tabular}{|c|c|c|c|c|c|}
\hline $\begin{array}{l}\text { Fonte } \\
\text { de Variação }\end{array}$ & G.L. & $\begin{array}{l}\text { Soma dos } \\
\text { Quadr. }\end{array}$ & Variância & $\mathrm{F}$ & $\mathbf{P}$ \\
\hline $\begin{array}{l}\text { A. Regressão } \\
\text { B. Linearidade } \\
\text { C. Entre grupos } \\
\text { Erro T- }(\mathbf{A}+\mathbf{B}+\mathrm{C}) \\
\quad \text { Totais }\end{array}$ & $\begin{array}{r}1 \\
1 \\
4 \\
8 \\
14\end{array}$ & $\begin{array}{r}2.755,60 \\
1,20 \\
13,73 \\
7,87 \\
2.778,40 \\
\end{array}$ & $\begin{array}{r}2.755,60 \\
1,20 \\
3,43 \\
0,98375\end{array}$ & $\begin{array}{r}2.801,11 \\
1,21 \\
3,48\end{array}$ & $\begin{array}{l}<0,01 \\
>0,05 \\
>0,05\end{array}$ \\
\hline $\mathrm{Y}=\mathrm{y}+\mathrm{b}(\mathrm{x}-\mathrm{x}$ & & $\mathrm{b}=\mathrm{Sxy}-$ & $y S x \quad y=$ & 21,8 & 0,7 \\
\hline $\begin{array}{l}\mathrm{Sx}=2,1 \mu \mathrm{g} \\
\mathrm{xSx}=1,47\end{array}$ & Sxy & $\begin{aligned} & S x^{2}- \\
= & 60,78 \\
= & 3,57\end{aligned}$ & $\begin{array}{l}\mathbf{x S x} \\
\mathrm{ySx}=45,7 \\
\mathrm{Y}=21,8\end{array}$ & $\begin{array}{r}S_{3}^{2}= \\
(x-57=\end{array}$ & $\begin{array}{l}1,89 \\
0,7)\end{array}$ \\
\hline
\end{tabular}

3. Ação da Succcinilcolina - Nos músculos estriados de Vertebrados admite-se que a Succinilcolina tem uma ação inibidora a da $\mathrm{ACh}$. Tratando-se de um leptocurare era o que se poderia esperar. O M.R.P., porém, reagiu de modo contrário, i.é, a Succinilcolina, na relação de $0.2 \mathrm{mg}$ para $1 \mu \mathrm{g}$ de $\mathrm{ACh}$ determinou uma resposta à $\mathrm{ACh}$ que é $20 \%$ maior que a ini- 
cial. O emprêgo de uma dose menor $(0.15 \mu \mathrm{g})$ de Succinilcolina, do mesmo modo que o anterior, não provocou reação do M.R.P., mas adicionando-se agora $10 \mu \mathrm{g}$ de $\mathrm{ACh}$, ainda é evidente uma ação potencializadora, da ordem de $10 \%$ como se vê na Fig. 15. Ėste efeito, porém, não persiste, pois, pràticamente, na repetição da experiência não houve mais a potencialização.

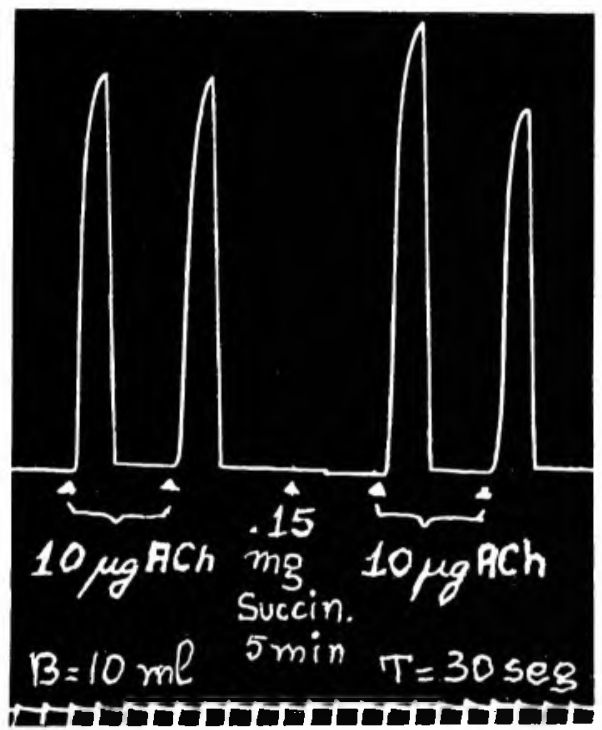

FIG. 15. Contrações do M.R.P. de M. perna. Efeito da Succinilcolina

\section{Ação de Inibidores}

a) Atropina - A Atropina na relação de $30 \mu \mathrm{g}$ para $2 \mu \mathrm{g}$ de ACh reduziu a contração de $30 \%$ da inicial e na relação de $100 \mu \mathrm{g} / 2 \mu \mathrm{g}$ provocou $50 \%$ de inibição da resposta (Fig. 16). O recobro, à lavagem, é pràticamente imediato.

b) Mitolon na concentração de $50 \mu \mathrm{g}$ determinou uma redução de $80 \%$ na amplitude da contração do músculo submetido à ação de $2 \mu \mathrm{g}$ de $\mathrm{ACh}$ (Fig. 17). Aquí, também, à lavagem, o recobro é imediato. 
c) A D-tubocurarina na concentração de $0.3 \mathrm{mg}$ determina uma redução de $75 \%$ da contração provocada por $2 \mu \mathrm{g}$

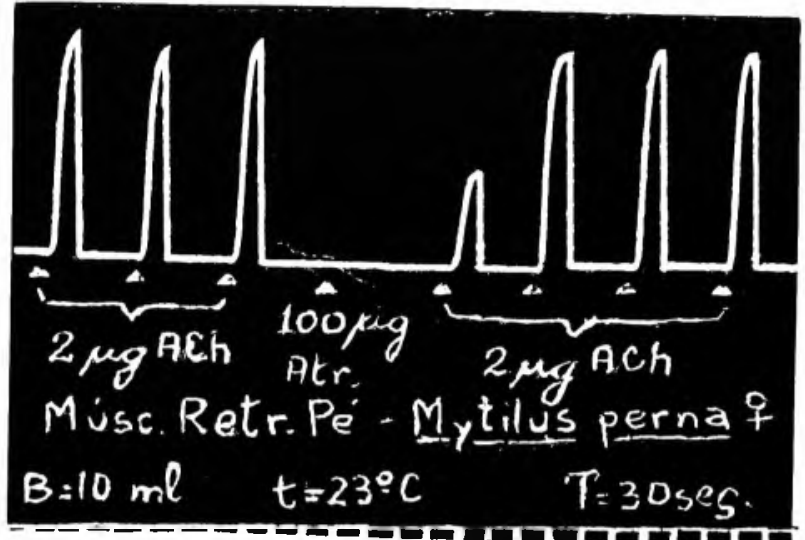

FIG. 16. Efeito da Atropina sôbre o M.R.P.

de ACh (Fig. 18) e o Flaxedil, nas mesmas condições, dá como resultado uma inibição total (Fig. 19). Igualmente nêstes casos houve recuperação total do músculo após a lavagem.

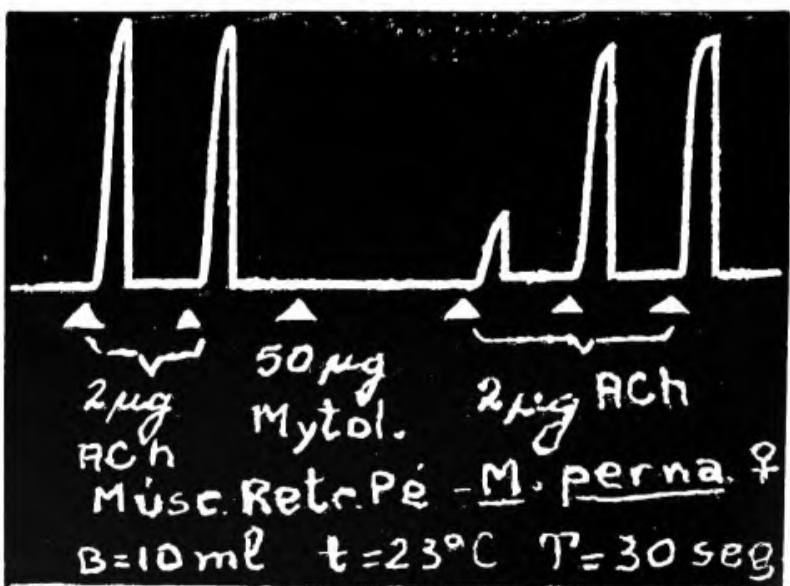

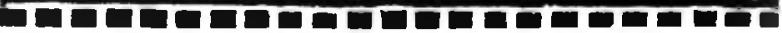

FIG. 17. M.R.P. Ação do Mitolon. 


\section{Ação do Mecolil, da Nicotina e da Pilocarpina}

A seguir, passei a fazer uma série de experiências com o emprêgo de substâncias como o Mecolil, a Nicotina, a Pilocarpina, drogas que agem em efetuadores dos sistemas colinérgicos. Desde logo, verifiquei que a Nicotina tem efeito sôbre êste músculo, a partir de $3 \mu \mathrm{g}$ sendo a resposta do mesmo deprimida pela Atropina e pelo Mitolon na concentração final de $1 \times 10^{-5}$. Também contra a Nicotina o Mitolon mostrou ser mais eficaz inibidor que a Atropina nêste tipo de músculo, o qual depois dêste tratamento passou a apresentar pequenas

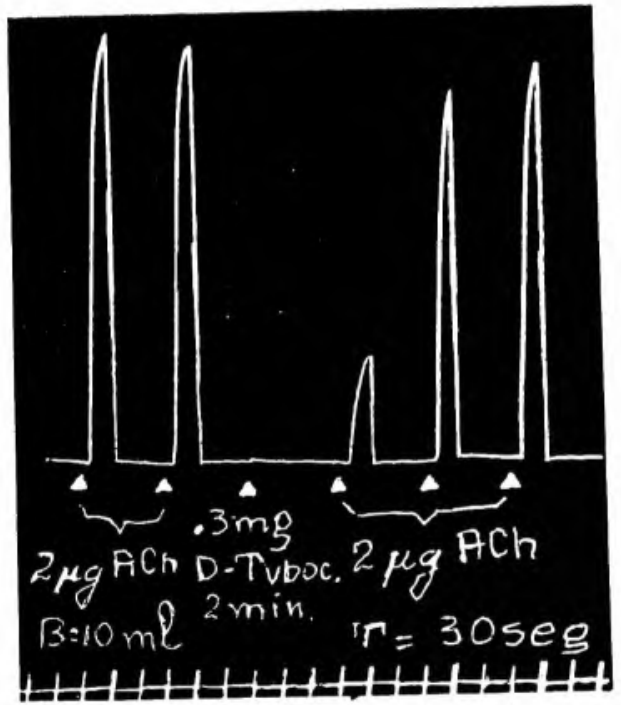

FIG. 18. M.R.P. Ação da D-tubocurarina que inibe em $75 \%$ a ação da ACh.

contrações espontâneas sucessivas (Fig. 20 e 21), ou seja, atividade rítmica. Nos experimentos, o Mitolon (0.1 mg) provocou diminuição do efeito da Nicotina $(0.1 \mathrm{mg})$; Atropina (0.1 mg) também inibiu a ação da Nicotina $(0.1 \mathrm{mg})$, mas seu efeito foi menor que o do Mitolon na mesma concentracão (0.1 mg). Êstes efeitos são bem evidentes no gráfico da Fig. 
21, que é continuação do gráfico da Fig. 20. Nêste gráfico, observamos ainda que a resposta do músculo à $\mathrm{ACh}$ foi deprimida pelo tratamento repetido com a Nicotina. Nos experimentos realizados, a Pilocarpina (2 $\mu \mathrm{g}$ e $5 \mu \mathrm{g}$ ) e o Mecolil $(10 \mu \mathrm{g})$, bem como a Histamina $(2 \mu \mathrm{g})$, não provocaram reação

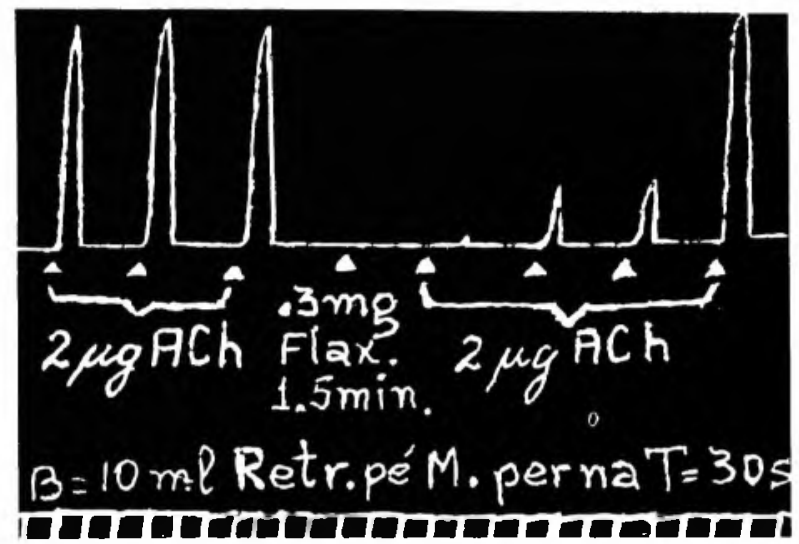

FIG. 19. M.R.P. de M. perna. Ação do Flaxedil.

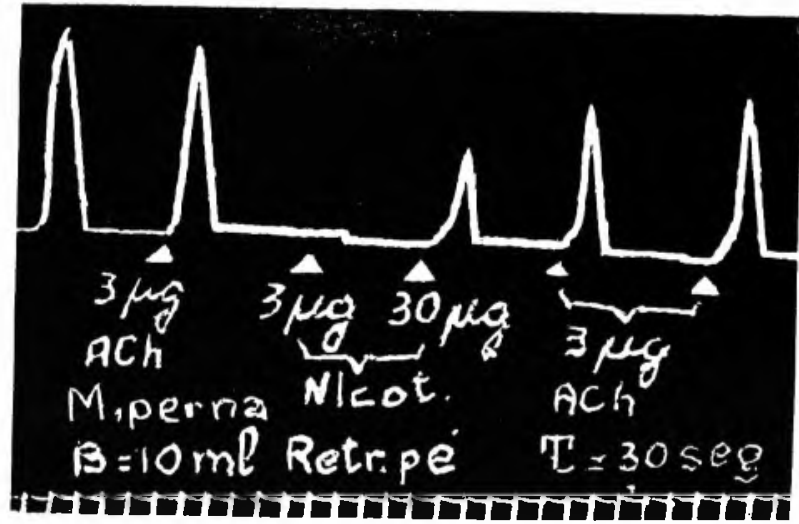

FIG. 20. Ação da Nicotina.

do M.R.P. Êsses agentes farmacológicos foram também testados em concentrações mais fortes (até $10^{-4}$ ) e, mesmo assim, não atuaram sôbre a preparação. 
6. Ação da Triptamina e Serotonina (5-HT)

A Triptamina per se não tem efeito sôbre o M.R.P. Fazendo agir a ACh $(2 \mu \mathrm{g})$ logo após a Triptamina $(0.1 \mathrm{mg})$,

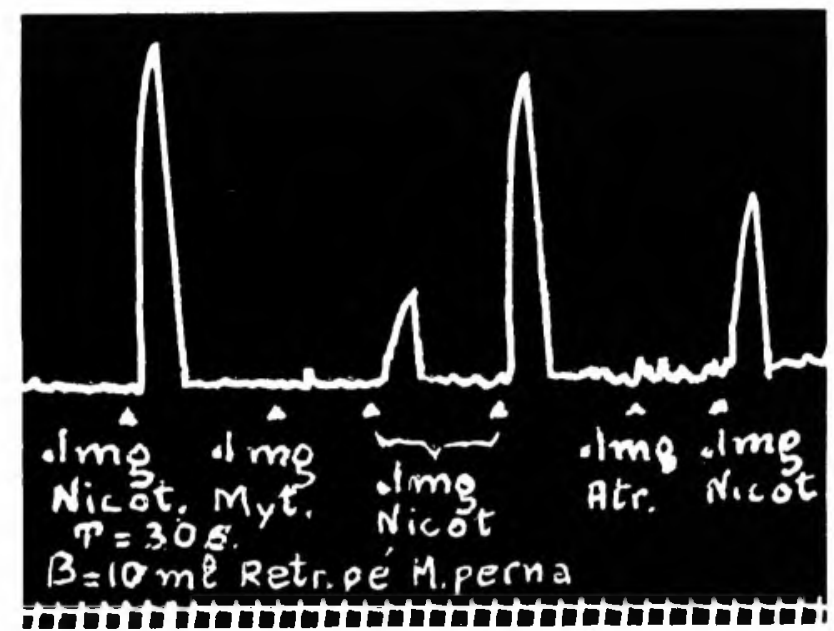

FIG. 21. M.R.P. - Inibição da Nicotina pelo Mitolon e pela Atropina.

nota-se uma diminuição da resposta ao éster, mas a ação da Triptamina não persiste, pois com uma estimulação pela $\mathrm{ACh}$ $(2 \mu \mathrm{g})$ a resposta aproximadamente equivale às respostas iniciais, ou até é potencializada.

Na Fig. 22 observam-se respostas a $2 \mu \mathrm{g}$ de ACh e administrações de Serotonina $(2 \mu \mathrm{g}$ e $20 \mu \mathrm{g})$. As contrações provocadas pela $\mathrm{ACh}$ sobreposta à Serotonina foram menores. A terceira resposta do músculo a $2 \mu \mathrm{g}$ de $\mathrm{ACh}$ mostra que logo após a lavagem houve recuperação.

Ainda mais, nem $100 \mu \mathrm{g}$ de Serotonina mostram ação direta sôbre o M.R.P. (Fig. 23). No caso, a preparação foi lavada e tratada novamente por ACh $(2 \mu \mathrm{g})$, observando-se o mesmo comportamento do músculo quando submetido à ação da $\mathrm{ACh}(2 \mu \mathrm{g})$ antes da adição de 5-HT. 
A Serotonina foi testada não só para verificar seu efeito sôbre a contração pela $\mathrm{ACh}$, como também para saber se atuaria na fase de relaxamento do M.R.P. contraído pela ACh. Convém salientar que o M.R.P., em todos os experi-

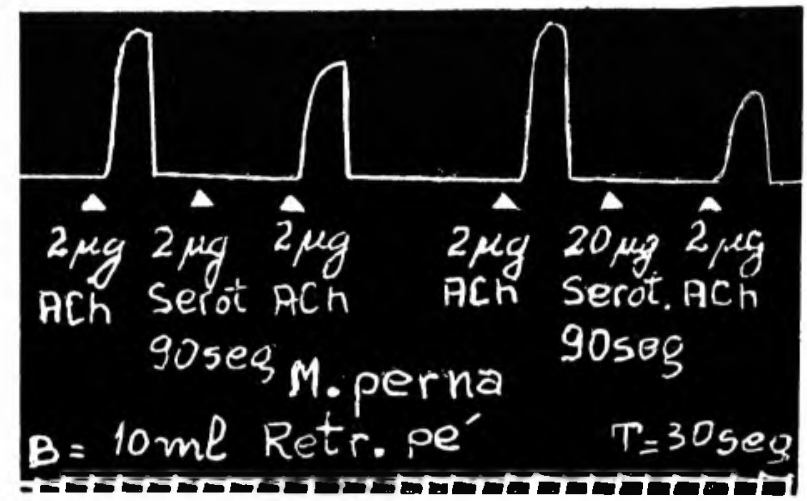

FIG. 22. M.R.P. - Efeito inibidor da Serotonina.

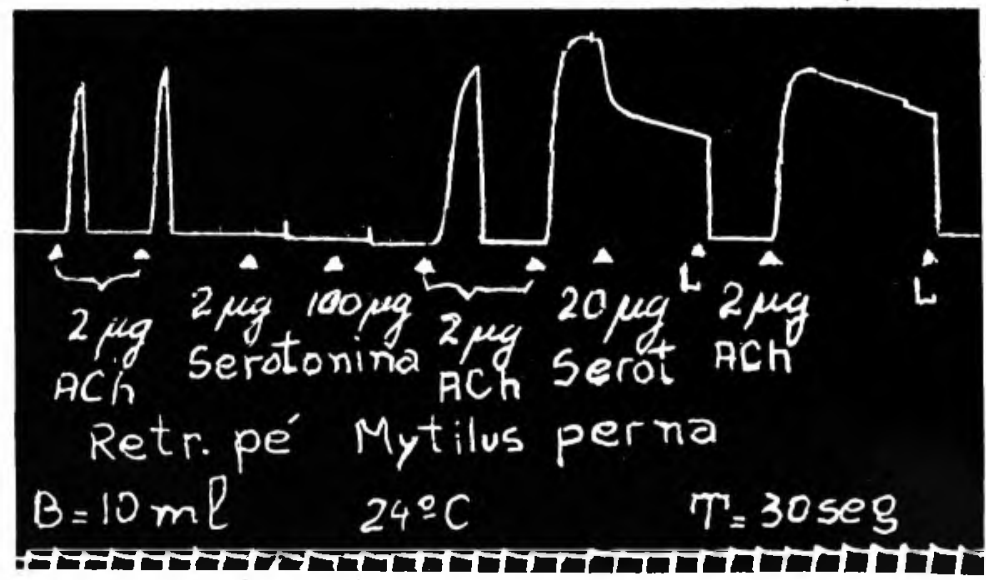

FIG. 23. M.R.P. - Serotonina x Relaxamento.

mentos, relaxou-se prontamente após a lavagem. Isto posto, depois da seguinte adição de $\mathrm{ACh}(2 \mu \mathrm{g})$ o músculo não foi lavado, porém, antes de adicionar Serotonina (20 $\mu \mathrm{g})$, esperei, 
com o cilíndro parado ( 2 minutos), que tivesse início o relaxamento por destruição natural da droga ( $\mathrm{ACh}$ ) pelo M.R.P. Adicionei, então, os $20 \mu \mathrm{g}$ de Serotonina e, durante dois minutos, fiz o registro da curva de relaxamento. Êste só se deu completa e ràpidamente quando lavei o músculo. Que a Serotonina não tem ação sôbre o relaxamento do M.R.P., foi comprovado, pois a seguir, adicionei novamente $2 \mu \mathrm{g}$ de $\mathrm{ACh}$, não parando o quimógrafo nem lavando a preparação durante três minutos. Aquí também, só com a lavagem da preparação, o músculo retornou à linha de base prontamente. Os níveis de relaxamento que se observam nessas duas últimas contrações são correspondentes ao tempo de permanência da ACh em contáto com o músculo, mostrando, portanto, que a . Serotonina não provoca nem acelera o relaxamento do M.R.P. Êste se dá de modo rápido, só quando se remove a $\mathrm{ACh}$ por lavagem da preparação.

Pelos resultados obtidos verifica-se que o M.R.P. é sensível a pequenas doses de ACh. As experiências de «doseefeito» indicam bôa relação entre molécula desta droga e receptor.

Além disso, potencializadores tais como a Fisostigmina, Prostigmina e inibidores tais como Mitolon, Atropina, D-tubocurarina, Flaxedil atuam sôbre o M.R.P. A Succinilcolina, embora incluída no grupo das drogas curarizantes, porém, provocou apenas ligeira potencialização da ação da $\mathrm{ACh}$ e nenhuma inibição.

A Nicotina, droga colino-mimética, teve dupla ação nêste músculo, i.é, provocou contração do músculo e deprimiu resposta dêste à $\mathrm{ACh}$.

Várias drogas não agem sôbre o M.R.P., tais como o Mecolil, a Pilocarpina e a Histamina.

Observei que a ação da Atropina, como se sabe, reduzindo a despolarização provocada pela $\mathrm{ACh}$, dá-se sòmente quando se empregam concentrações de Atropina relativamente altas, em comparação com as utilizadas em músculos lisos de Vertebrados, para obtenção do mesmo efeito. 
A Serotonina não produz efeito no músculo, quando aplicada isoladamente e nem mesmo modifica a ação da $\mathrm{ACh}$, quanto ao relaxamento. Por outro lado, deprime a contração do M.R.P. à $\mathrm{ACh}$ (Fig. 22), quando prèviamente adicionada sem lavagem.

\section{b) MŨSCULO RETRATOR ANTERIOR DO BISSO (M.R.A.B.)}

Embora o principal objetivo dêste trabalho, na parte farmacológica, tenha sido verificar as respostas do músculo retrator do pé, procurei estudar também as do M.R.A.B. principalmente para poder avaliar se o seu comportamento corresponde ao quanto vem sendo estudado e discutido por inúmeros autores, como FLETCHER 1937a, p. 234; TWAROG 1949, p. 57 ; 1954 , p. 141; HOYLE \& LOWY 1956, p. 295; CAMBRIDGE, HOLGATE \& SHARP 1958, p. 459 e outros.

Para propiciar um estudo comparativo, empreguei as mesmas drogas já indicadas na parte referente ao M.R.P.

1. Ação da Acetilcolina - Sob a influência desta droga os efeitos foram diferentes dos obtidos para o M.R.P. O limiar verificado foi em tôrno de $0.2 \mu \mathrm{g}$ (Fig. 24). $\overline{\mathrm{E}}$ característico o tipo de contração sustentada dêste músculo, provocada pela $\mathrm{ACh}$ (Fig. 25). A fase de lento relaxamento não se modifica, mesmo com a lavagem da preparação. Nêste particular difere do M.R.P., no qual após a lavagem (Fig. 23), o relaxamento é imediato.

Êste comportamento singular do M.R.A.B. em relação à estimulação pela $\mathrm{ACh}$ tornou difícil o seu estudo nas mesmas condições em que se fez a investigação com o M.R.P. para uma comparação. Ẽ sabido, porém, que a Serotonina abole a contração tônica provocada pela ACh (HOYLE, LOWY 1956, p. 295).

Procurei, pois, no caso do M.R.A.B., valer-me dessa droga para tentar acelerar o relaxamento após o tratamento 
com ACh. Isso foi conseguido (Fig. 25) e, assim, possibilitou o uso da mesma preparação, em bôas condições para o estudo da resposta fásica.

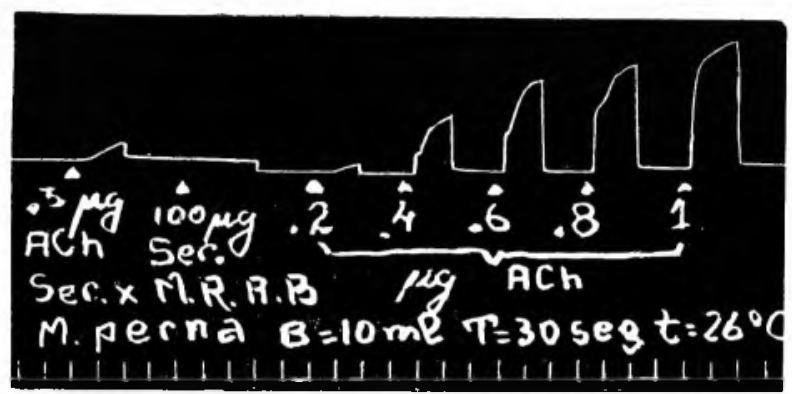

FIG. 24. M.R.A.B. - Sensibilidade à ACh. Curva dose-efeito.

Após a administração de $2 \mu \mathrm{g}$ de $\mathrm{ACh}$, obtem-se a contração sustentada. Na Fig. 25, vê-se que o relaxamento é ace-

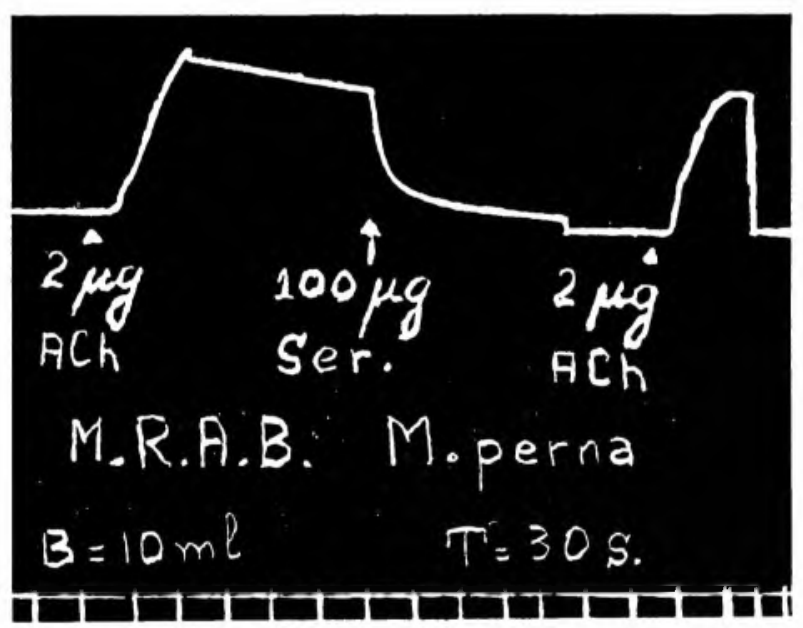

FIG. 25. M.R.A.B. - Contração tônica pela ACh. Serotonina. Contração fásica pela $\mathrm{ACh}$.

lerado por $100 \mu \mathrm{g}$ de Serotonina. Nota-se nitidamente, a abolição da contração sustentada pela Serotonina. Nas seguintes 
adições de $\mathrm{ACh}$, a resposta a esta droga, torna-se do tipo fásico, com relaxamento rápido à lavagem.

Comprovada a ação relaxante da Serotonina sôbre o M.R.A.B., determinei a concentração desta substância que provocava a abolição da resposta tônica à $\mathrm{ACh}$ durante tôda a experiência (duração aproximada de duas horas) registrando que a dose adequada era de $100 \mu \mathrm{g}$, com incubação de dez minutos. A seguir, o músculo era lavado e pude prosseguir com a execução das experiências programadas. Na Fig. 24, notam-se respostas do músculo, que media $\mathrm{cm} 0.5$ de comprimento logo após a excisão e $\mathrm{cm} 0.8$ quando totalmente relaxado, sujeito à $\mathrm{ACh}$ em concentraçes crescentes de $0.2 \mu \mathrm{g}$ e $1 \mu \mathrm{g}$, i.é, nas doses de $2 \times 10^{-8}$ a $1 \times 10^{-7}$.

Para a análise estatística das relações entre a concentração da droga e o efeito obtido, utilisei três doses de $\mathbf{0 . 3}$, 0.6 e $1.2 \mu \mathrm{g}$ na razão de 1:2 em três grupos de três.

A análise dos resultados revelou significante linha de regressão e não significante desvio de linearidade: portanto, as respostas seguiram uma linha reta (Fig. 27). A razão de

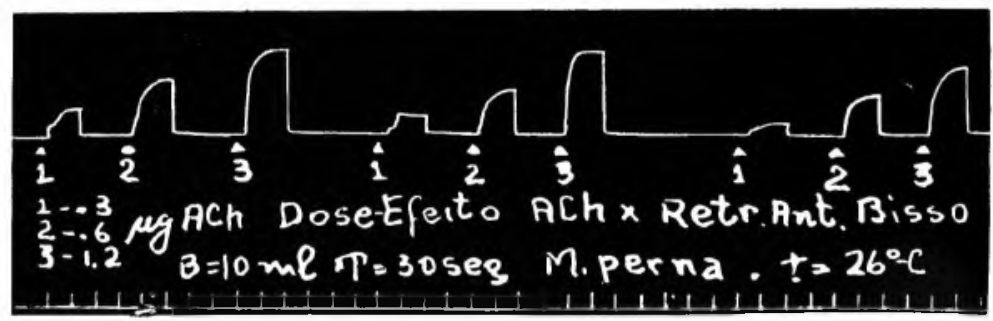

FIG. 26. M.R.A.B. - Dose-efeito, ACh.

variação entre os grupos foi significante, indicando pequena variação da sensibilidade durante a experiência. $O$ êrro padrão $\mathrm{S}=0,288$ representou $6 \%$ da média para tôdas as determinações $\Lambda$ s Figs. 26, 27 e a tabela II mostram as respostas e os dados obtidos nas experiências dose-efeito. 
2. Potencialização da Acetilcolina - Fisostigmina, a $0.5 \mu \mathrm{g}\left(5 \times 10^{-8}\right)$, aumentou de $30 \%$ resposta à $2 \mu \mathrm{g} \mathrm{ACh}$ $\left(2 \times 10^{-7}\right)$ (Fig. 28).

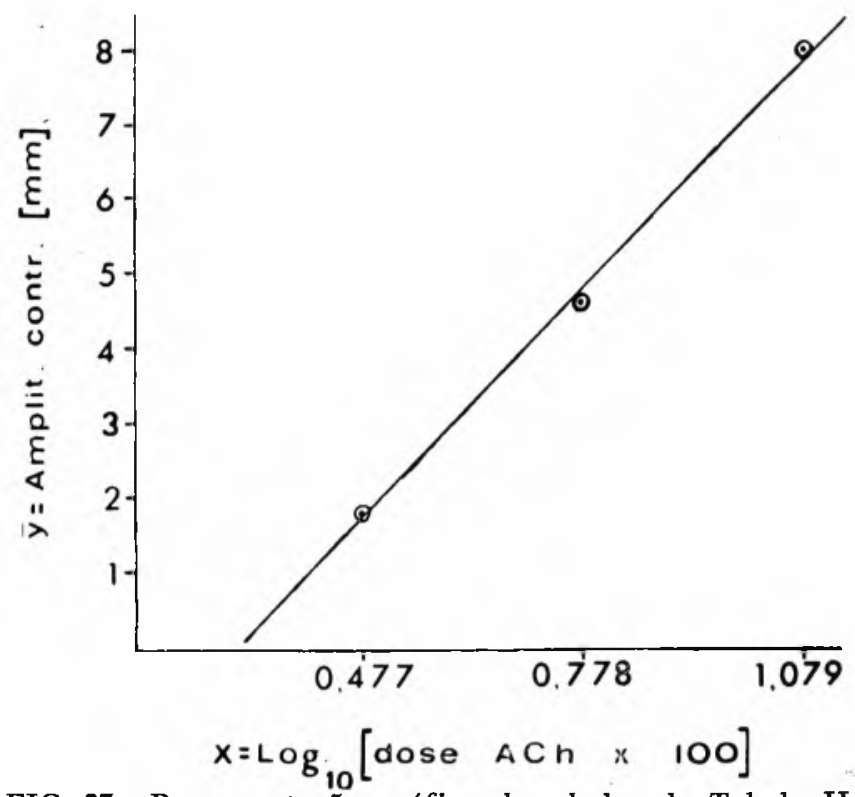

FIG. 27. Representação gráfica dos dados da Tabela II.

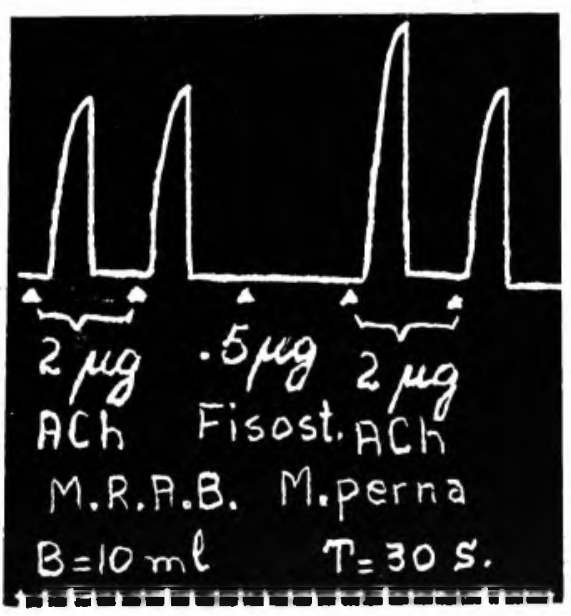

FIG. 28. M.R.A.B. - Potencialização da ACh pela Fisostigmina. 
T A B E L A I I

ANALISE ESTATISTICA DOS DADOS DA CURVA DOSE-EFEITO Acetilcolina x Músculo Retrator Anterior do Bisso de Mytllus perna

\begin{tabular}{|c|c|c|c|c|c|c|}
\hline Doses & Grupos & I & II & III & Td & $\overline{Y d}$ \\
\hline $\begin{array}{l}1 .{ }^{a} \\
2 . \\
3 .{ }^{a}\end{array}$ & $\begin{array}{r}.3 \mu \mathrm{g} \\
.6 \mu \mathrm{g} \\
1.2 \mu \mathrm{g} \\
\mathrm{Tg} \\
\mathrm{Yg}\end{array}$ & $\begin{array}{r}2,5 \\
5,5 \\
8,5 \\
16,5 \\
5,5 \\
\end{array}$ & $\begin{array}{c}2 \\
4,5 \\
8,5 \\
15 \\
5 \\
\end{array}$ & $\begin{array}{r}1 \\
4 \\
7 \\
12 \\
4 \\
\end{array}$ & $\begin{array}{c}5,5 \\
14 \\
24 \\
43,5 \\
Y \\
\end{array}$ & $\begin{aligned} & 1,83 \\
& 4,66 \\
&= 8 \\
&= T \\
&= 4,83 \\
&\end{aligned}$ \\
\hline
\end{tabular}

\begin{tabular}{llrrrrr}
\hline Coef./doses & & $\mathrm{K}$ & & $\mathrm{nSK}^{2}$ & SKTd & $\begin{array}{c}\text { (SKTd) }^{2} \\
\text { nSK }^{2}\end{array}$ \\
\hline A. Linear & -1 & 0 & +1 & 6 & 18,5 & 57,041 \\
B. Quadrático & +1 & -2 & +1 & 18 & 1,5 & 0,125 \\
$\quad$ Td & 5,5 & 14 & 24 & & & 57,166 \\
\hline
\end{tabular}

ANALISE DA VARIÂNCIA DOS DADOS DA TABELA

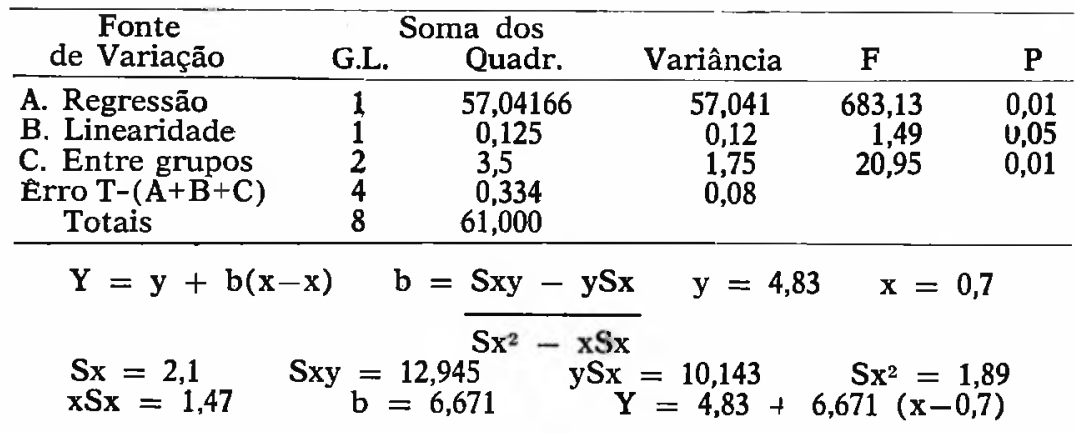

3. Inibição da Acetilcolina - A Succinilcolina, na dose de $100 \mu \mathrm{g}\left(1 \times 10^{-5}\right)$ não agiu diretamente sôbre o músculo, nem interferiu na contração provocada por $5 \mu \mathrm{g}$ de $\mathrm{ACh}$ $\left(5 \times 10^{-7}\right)$.

Dentre os agentes inibidores testados, o Mitolon (Fig. 29) foi o mais eficaz, pois, $50 \mu \mathrm{g}\left(5 \times 10-{ }^{6}\right)$ inibiram $70 \%$ da contração obtida com $5 \mu \mathrm{g}$ de $\mathrm{ACh}\left(5 \times 10-{ }^{7}\right)$, ao passo que $50 \mu \mathrm{g}$ de Atropina $\left(5 \times 10^{-6}\right)$ (Fig. 30) inibiram apenas $50 \%$ da res- 
posta a $3 \mu \mathrm{g}$ de $\mathrm{ACh}\left(3 \times 10^{-7}\right)$. A D-tubocurarina. na dose de $50 \mu \mathrm{g}\left(5 \times 10^{-6}\right)$ inibiu $30 \%$ da resposta (Fig. 31) a $4 \mu \mathrm{g}$ de ACh $\left(4 \times 10^{-7}\right)$, sendo mais eficaz que o Flaxedil. Êste adicionado em dose de $100 \mu \mathrm{g}\left(10^{-5}\right)$, inibiu $40 \%$ da resposta (Fig. 32) obtida pela adição de $4 \mu$ g de ACh $\left(4 \times 10^{-7}\right)$.

$\mathrm{Na}$ relação de $\mathrm{ACh}$ : Inibidor, os resultados foram os seguintes:

$\begin{array}{ll}\text { Succinilcolina } & 1: 20 \text { - não agiu } \\ \text { Mitolon } & 1: 10 \text { - inibiu } 70 \% \\ \text { Atropina } & 1: 16,7 \text { - inibiu } 50 \% \\ \text { D-tubocurarina } & 1: 12,5 \text { - inibiu } 30 \% \\ \text { Flaxedil } & 1: 25 \text { - inibiu } 40 \%\end{array}$

Em todos os casos houve recuperação total, após a respectiva lavagem. Para Mitolon, D-tubocurarina e Flaxedil,

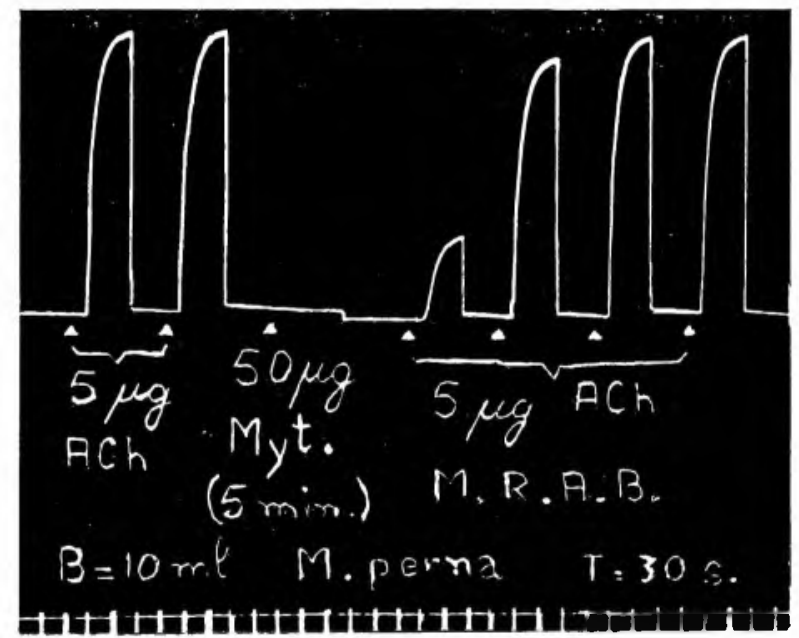

FIG. 29. M.R.A.B. - Ação do Mitolon.

esta se deu na segunda adição das doses de $\mathrm{ACh}$, ao passo que a Atropina mostrou ação mais persistente e a recuperação total só foi obtida na quarta adição das doses de ACh. 
4. Drogas colinérgicas - Mecolil e Pilocarpina.

Mecolil foi testado em várias doses, inclusive numa concentração final $\left(1 \times 10^{-4}\right)$ que se supõe, seja o limite da ação

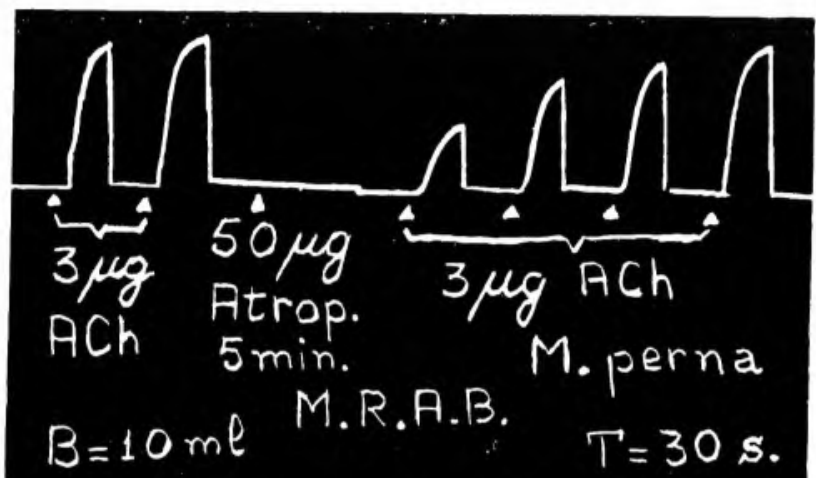

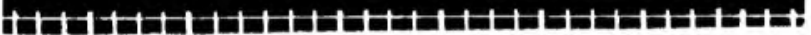

FIG. 30. M.R.A.B. - Ação da Atropina.

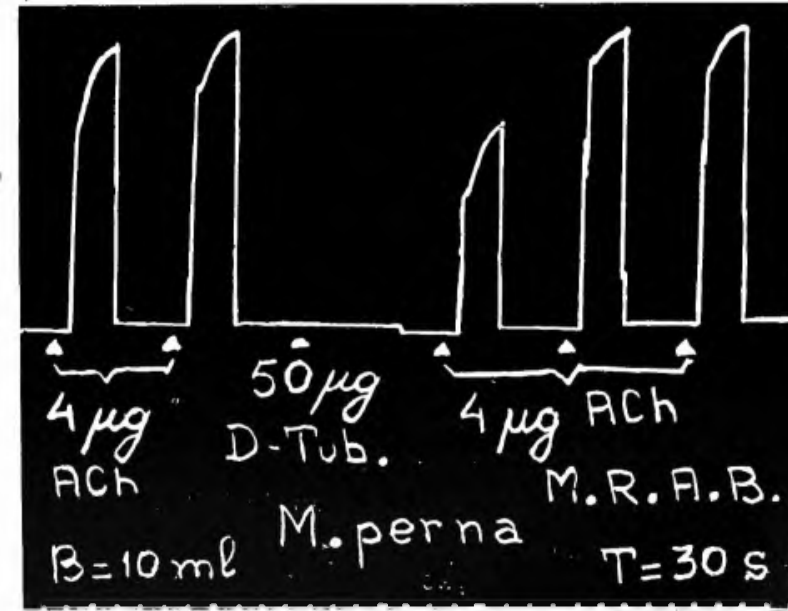

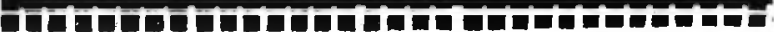

FIG. 31. M.R.A.B. - Ação da D-tubocurarina. 
fisiológica, não tóxica, da droga, sem que a preparação tenha manifestado qualquer reação. Verificamos que $5 \mu \mathrm{g}$ de $\mathrm{Me}-$ colil $\left(5 \times 10^{-7}\right)$ adicionados à preparação antes da sobreposição

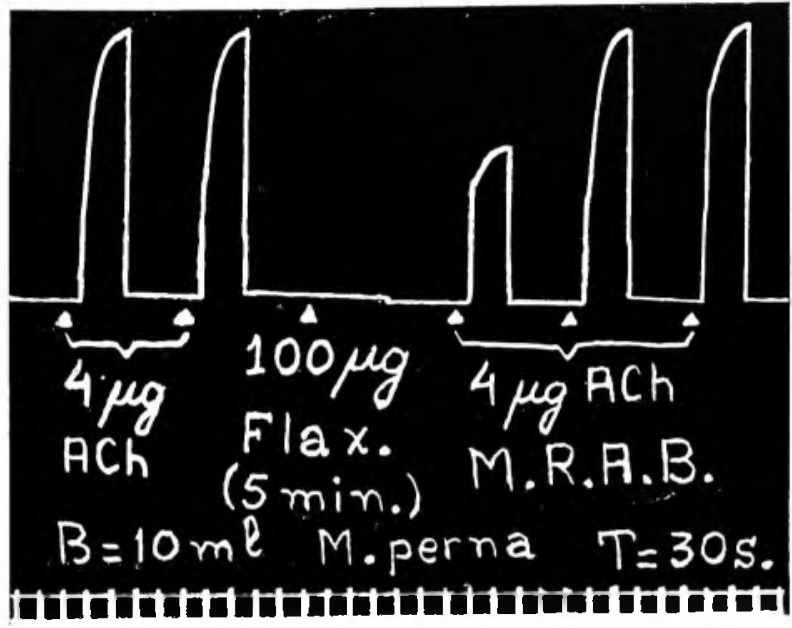

FIG. 32. M.R.A.B. - Ação do Flaxedil.

de $5 \mu \mathrm{g}$ de $\mathrm{ACh}\left(5 \times 10^{-\tau}\right)$ concorrem para ligeiro aumento da contração. A Pilocarpina foi também utilizada em várias doses e nem $100 \mu \mathrm{g}\left(10^{-5}\right)$ agiram sôbre o músculo.

5. Ação de drogas sôbre o relaxamento: Serotonina, Adrenalina e Atropina.

O efeito relaxante da Serotonina já foi abordado na p. 51.

A Adrenalina e a Atropina, por sua vêz, não modificaram substancialmente o relaxamento dêsse músculo contraido pela $\mathrm{ACh}$, tanto no tratamento prévio bem como adicionadas na fase de lento relaxamento. Servem apenas para realçar o efeito da Serotonina, abolindo a contração tônica num tratamento prévio ou relaxando prontamente o M.R.A.B. tônicamente contraído.

Resumindo, os resultados obtidos nesta série de experiências verifica-se comportar-se o M.R.A.B. diferentemente, 
do M.R.P. Responde tônicamente à $\mathrm{ACh}$, mas fasicamente à mesma se tratado com Serotonina.

$\bar{A}$ resposta à $\mathrm{ACh}$ é potencializada pela Fisostigmina, mas não pela Prostigmina.

No que se refere aos inibidores, nota-se que a Succinilcolina não produz efeito em relação à $\mathrm{ACh}$, mas o Mitolon tem uma ação bastante acentuada como agente inibidor da mesma. O mesmo acontece com a Atropina, a D-tubocurarina, e o Flaxedil.

Das outrąs drogas experimentadas, o Mecolil mostrou, em relação à $\mathrm{ACh}$, efeito sinérgico aditivo. A ação da Serotonina é bem singular, acelerando o relaxamento, sem interferir porém, na excitação do músculo pela $\mathrm{ACh}$.

\section{c) MÚSCULO RETRATOR POSTERIOR DO BISSO (M.R.P.B.)}

Ėste músculo não mereceu tanto a atenção dos pesquisadores, talvez pela dificuldade que apresenta na dissecção para ser libertado da concha e no $\boldsymbol{M}$. edulis, por apresentar-se subdividido em várias unidades ao nível de suas inserções.

1. Ação da Acetilcolina - Desde o início dos experimentos com êste músculo, notei comportar-se o mesmo como o M.R.A.B. Anotei, no entretanto, diferenças quanto ao limiar para $\mathrm{ACh}$, que corresponde a $0.5 \mu \mathrm{g}\left(5 \times 10^{-8}\right)$ e a sustentação da cantração, mais acentuada no presente caso. 0 mesmo tratamento prévio por $100 \mu \mathrm{g}$ de Serotonina foi utilizado para eliminar-se a resposta tônica. Portanto, tôdas as drogas foram testadas sôbre a resposta fásica que o músculo passa a mostrar depois de incubado com Serotonina durante 10 minutos. A curva de sensibilidade à $\mathrm{ACh}$ obteve-se com doses crescentes de $0.5 \mu \mathrm{g}\left(5 \times 10^{-8}\right)$ a $5 \mu \mathrm{g}\left(5 \times 10^{-7}\right)$ num músculo que media em $\mathrm{cm} 0.6$ logo depois da excisão e 1,2 no início da experiência.

A análise estatística dos resultados conseguidos pela adição de 3 doses de $\mathbf{A C h}(1,2$ e $4 \mu \mathrm{g})$ na razão $1: 2$, repetidas 
em 3 grupos, comprovou que as respostas transformadas de relação geométrica para escala logarítmica seguiram a linha reta. A linha de regressão mostrou ser significante, embora com desvio da linearidade, nos limites da significância. A razão da variação entre grupos, foi não significante, indicando que a sensibilidade da preparação não sofreu variação substancial no decorrer do experimento. $O$ êrro padrão, $S=0,645$, representou mais que $10 \%$ da média para tôdas as determinações. $\overline{\mathbf{E}}$ o que constatamos na Fig. 33 e na tabela III.

2. Inibição da Acetilcolina - Também nêsse caso a Succinilcolina, um leptocurare, não agiu de modo algum mesmo em doses de $200 \mu \mathrm{g}(2 \times 10-5)$ contra $20 \mu \mathrm{g}$ de $\mathrm{ACh}\left(2 \times 10-{ }^{6}\right)$.

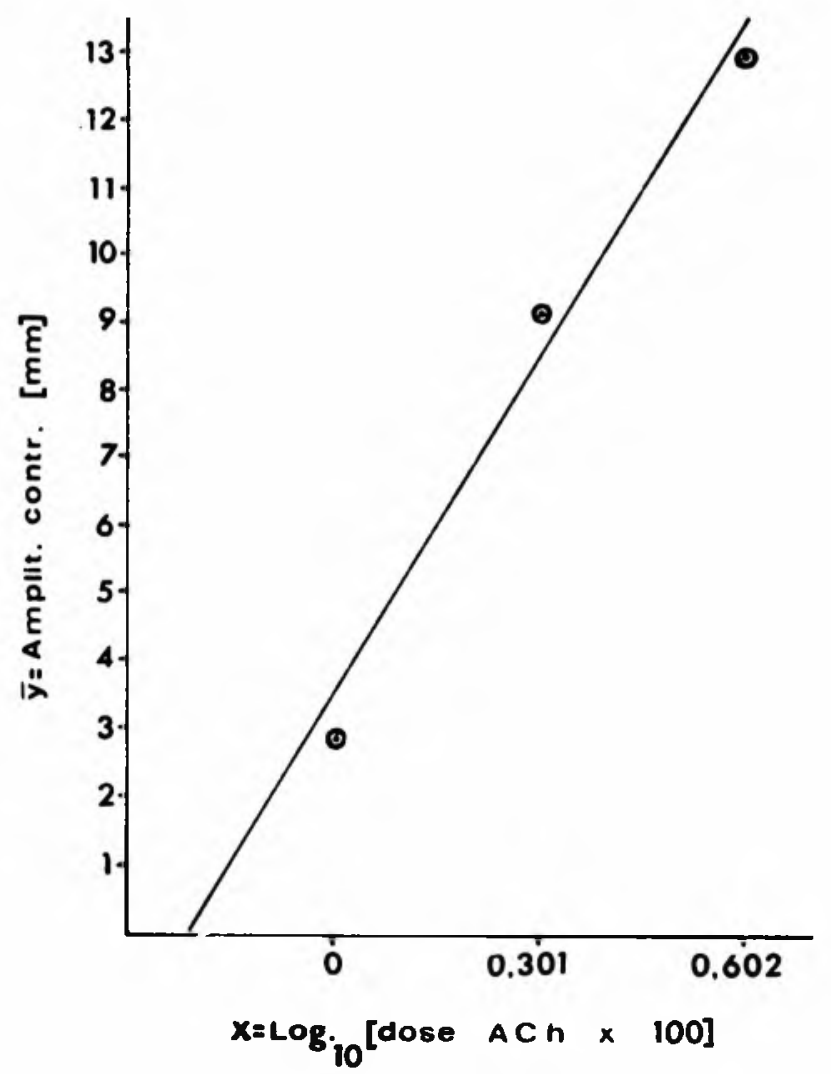

FIG. 33. Representação gráfica dos dados da Tabela III. 
T A B E L A I I I

ANALISE ESTATISTICA DOS DADOS DA CURVA DOSE-EFEITO Acetilcolina x Músculo Retrator Posterior do Bisso de Mytilus perna

\begin{tabular}{|c|c|c|c|c|c|c|}
\hline Doses & Grupos & I & II & III & $\mathrm{Td}$ & $\mathrm{Yd}$ \\
\hline $\begin{array}{l}1{ }^{a}{ }^{a} \\
3{ }^{2}{ }^{a}\end{array}$ & $\begin{array}{l}1 \mu \mathrm{g} \\
2 \mu \mathrm{g} \\
4 \mu \mathrm{g} \\
\mathrm{Tg} \\
\mathrm{Yg}\end{array}$ & $\begin{array}{c}3 \\
10,5 \\
14 \\
27,5 \\
9,16 \\
\end{array}$ & $\begin{array}{c}3 \\
9,5 \\
13 \\
25,5 \\
8,5\end{array}$ & $\begin{array}{c}2,5 \\
7,5 \\
12 \\
22 \\
7,33\end{array}$ & $\begin{array}{l}8,5 \\
27,5 \\
39 \\
75 \\
Y\end{array}$ & $\begin{aligned} & 2,83 \\
& 9,16 \\
& 13 \\
&=\quad \mathrm{T} \\
&=8,33\end{aligned}$ \\
\hline
\end{tabular}

\begin{tabular}{lcccccc}
\hline & & & & & & $\frac{(\mathrm{SKTd})^{2}}{$\cline { 3 - 5 } \text {$Coef./doses }}$ \\
& $\mathrm{K}$ & & $\mathrm{nSK}^{2}$ & $\mathrm{SKTd}$ & $\mathrm{nSK}^{2}$ \\
\hline A. Linear & -1 & 0 & +1 & 6 & 30,5 & 155,041 \\
B. Quadrático & +1 & -2 & +1 & 18 & $-7,5$ & 3,125 \\
$\quad$ Td & 8,5 & 27,5 & 39 & & & 158,166 \\
\hline
\end{tabular}

ANALISE DA VARIÂNCIA DOS DADOS DA TABELA

\begin{tabular}{|c|c|c|c|c|c|}
\hline $\begin{array}{c}\text { Fonte } \\
\text { de Variação }\end{array}$ & G.L. & $\begin{array}{l}\text { Soma dos } \\
\text { Quadr. }\end{array}$ & Variância & $\mathrm{F}$ & $\mathbf{P}$ \\
\hline $\begin{array}{l}\text { A. Regressão } \\
\text { B. Linearidade } \\
\text { C. Entre grupos } \\
\text { Erro T- }(A+B+C) \\
\text { Totais } \\
\end{array}$ & $\begin{array}{l}1 \\
1 \\
2 \\
4 \\
8 \\
\end{array}$ & $\begin{array}{c}155,0416 \\
3,125 \\
5,1666 \\
1,6668 \\
165,0000\end{array}$ & $\begin{array}{r}155,041 \\
3,125 \\
2,5833 \\
0,4167\end{array}$ & $\begin{array}{r}327,07 \\
7,4994 \\
6,1994\end{array}$ & $\begin{array}{l}0,01 \\
0,05 \\
0,05\end{array}$ \\
\hline$Y=y+b(x$ & & $\mathrm{b}=\mathrm{Sxy}-$ & $\mathrm{y}=$ &, 33 & \\
\hline $\begin{array}{l}\mathrm{Sx}=7 \mu \mathrm{g} \\
\mathrm{xSx}=16,21\end{array}$ & \multicolumn{2}{|c|}{$\begin{aligned} \mathrm{Sxy} & =73,15 \\
\mathrm{~b} & =3,118\end{aligned}$} & $\begin{array}{c}\mathrm{xSx} \\
\mathrm{ySx}=58,2 . \\
\mathrm{Y}=8,33\end{array}$ & $\begin{array}{r}S^{2} \\
3,118(x\end{array}$ & \\
\hline
\end{tabular}

Na Fig. 34 é evidente que Mitolon é eficaz, sendo um dos mais potentes inibidores usados. Na dose de $40 \mu \mathrm{g}\left(4 \times 10^{-6}\right)$ agiu antagonizando $4 \mu \mathrm{g}$ de $\mathrm{ACh}$ com redução de $90 \%$ da resposta a esta última droga.

Já a Atropina $(100 \mu \mathrm{g})$ provocou $50 \%$ de redução na resposta do músculo à $20 \mu \mathrm{g}$ de $\mathrm{ACh}\left(2 \times 10^{-6}\right)$ (Fig. 35).

A D-tubocurarina em doses de $200 \mu \mathrm{g}\left(2 \times 10^{-5}\right)$ inibiu $50 \%$ da contração exibida pela preparação à adição de $20 \mu \mathrm{g}$ 
de $\mathrm{ACh}\left(2 \times 10^{-6}\right)$ (Fig. 36) sendo mais potente que o Flaxedil (Fig. 37), o qual utilizado nas mesmas doses reduziu a resposta de $30 \%$.

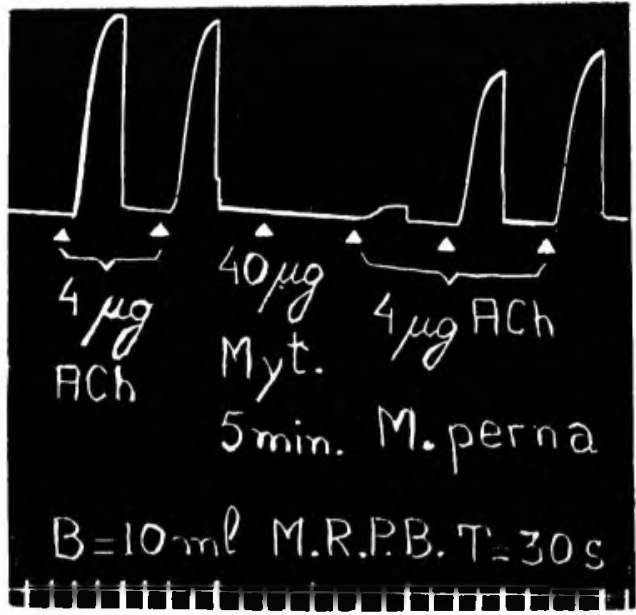

FIG. 34. M.R.P.B. - Ação do Mitolon.

Também nêsse músculo, as preparações exibiram à lavagem, curva de recuperação até o nível anterior ao do tratamento pelos antagonistas.

3. Ação da Nicotina - Das outras drogas que têm ação sôbre efetuadores dos sistemas colinérgicos, empreguei a Nicotina e pude observar a sensibilidade dêsse músculo à essa droga. A ACh e Nicotina foram usadas na mesma dose, ou seja $2 \mu \mathrm{g}$, porém a amplitude da contração obtida com Nicotina foi o dôbro da obtida com ACh.

4. Ação da Serotonina e L.S.D. - Nêste músculo, a serotonina age da mesma forma que no M.R.A.B. A Fig. 38 mostra contrações mantidas provocadas por $1 \mu \mathrm{g}\left(1 \times 10^{-7}\right) \mathrm{de}$ $\mathrm{ACh}$, depois de ter sido lavada a preparação e a adição de $100 \mu \mathrm{g}$ de Serotonina provocando relaxamento total do músculo. A seguir doses de ACh provocando contrações fásicas. 
Quanto ao Bromo-L.S.D., conhecido inibidor da Serotonina (5-HT), o músculo mostrou ligeríssima sensibilidade à adição de 100 ug (1×10-5).

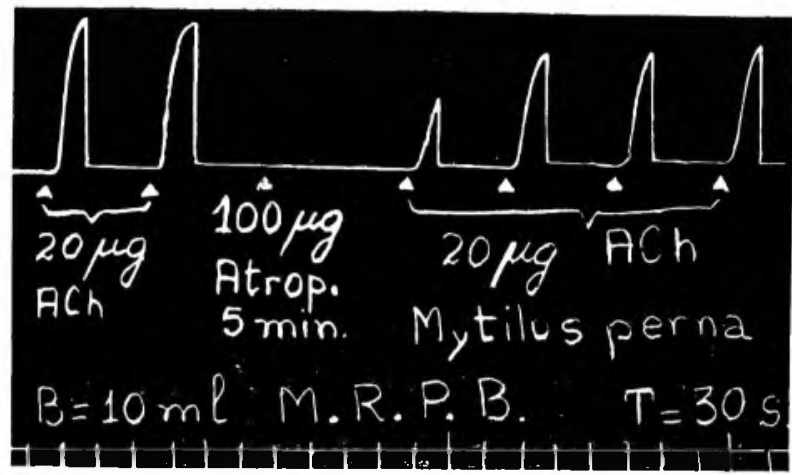

FIG. 35. M.R.P.B. - Ação da Atropina.

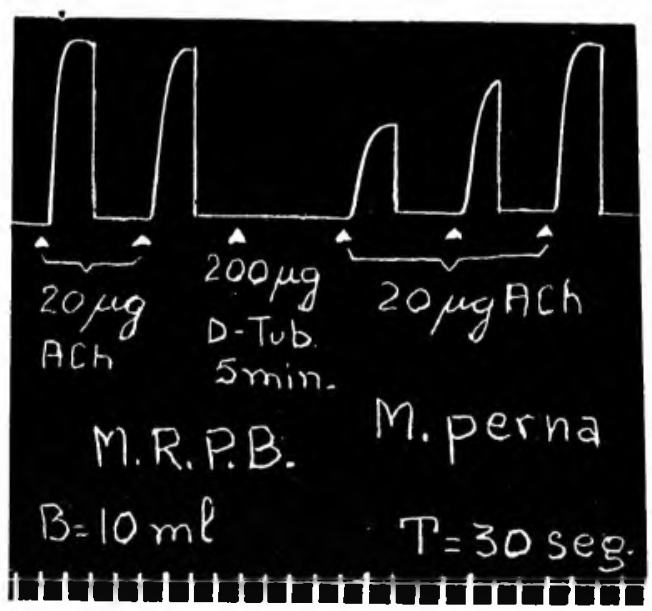

FIG. 36. M.R.P.B. - Ação da D-tubocurarina.

$\mathrm{Na}$ adiçāo ulterior de $\mathrm{ACh}$, depois de lavada a preparação, o músculo contraiu-se e relaxou-se várias vêzes, e depois, manteve-se parcialmente contraido, por algum tempo. 
Sumariando os resultados desta última série de experiências, verifica-se que o comportamento do M.R.P.B. não difere fundamentalmente do M.R.A.B. Os limiares de exci-

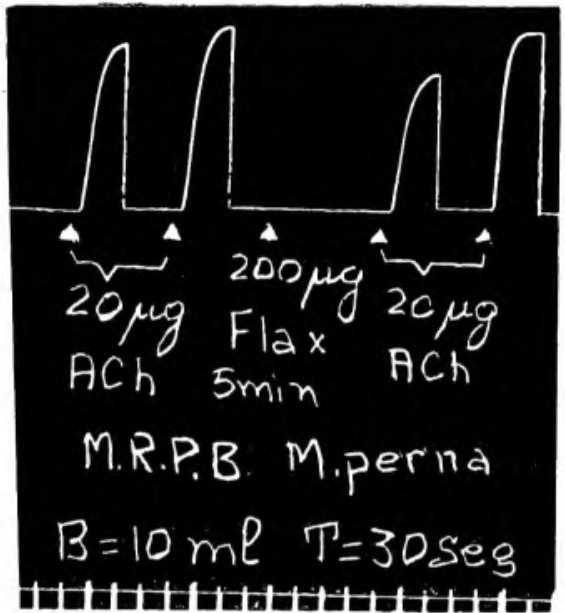

FIG. 37. M.R.P.B. - Ação do Flaxedil.

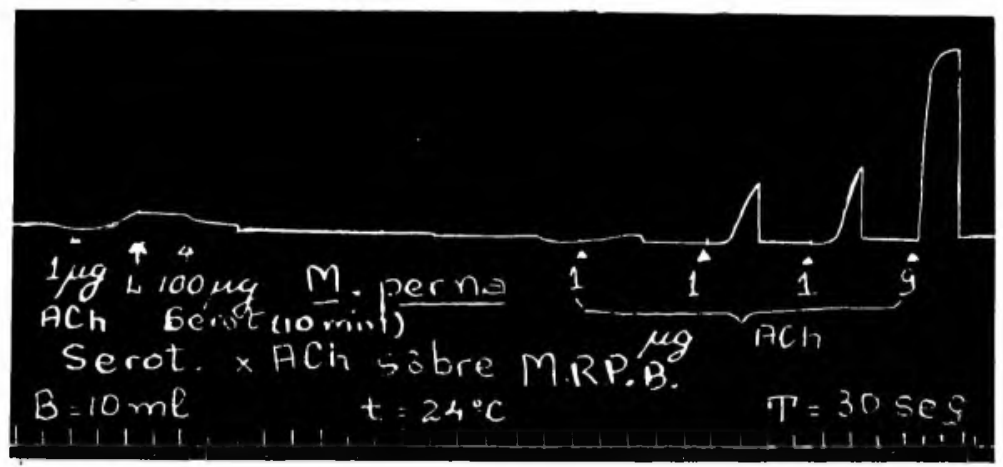

FIG. 38. M.R.P.B. - Ação da Serotonina.

tação são próximos nos dois músculos. Para se obter a eliminação da resposta tônica foi necessário, aqui também, o tratamento prévio pela Serotonina. A ação da Succinilcolina, também aquí, ao contrário do que ocorreu com o M.R.P., não 
produziu efeito, tal como ocorreu no M.R.A.B. Os potencializadores e os inibidores da Acetilcolina não diferiram na sua ação quanto ao que se observou com o M.R.A.B. O mesmo aconteceu com a Serotonima.

Neste caso, foi possível, empregar o ácido D-bromo lisérgico; na concentração de $100 \mu \mathrm{g}$ induz ligeira contração. Contrações espontâneas ocoreram durante a posterior estimulação por ACh na concentração de $2 \mu \mathrm{g}$, após a lavagem, na segunda experiência. Além disso a ação da Nicotina $(2 \mu \mathrm{g})$ foi evidente, manifestando-se por uma contração sustentada uniforme.

6.

\section{I S C USS Ã O}

No presente trabalho procurou-se dar ênfase à fisiologia e à farmacologia do M.R.P., até agora, pelo que pude verificar na bibliografia disponível, não abordado sob êste aspecto.

Segundo os resultados verificados, êsse músculo difere no seu comportamento do M.R.A.B. E sensível à ACh, sendo $1 \times 10^{-8}$ a concentração limiar. $O$ éster, após excitar o músculo, não provoca a contração sustentada, contràriamente ao que ocorre com os M.R.A.B. e M.R.P.B. Realmente, o que se dá é uma contração rápida, com um tempo de latência de um segundo; a esta contração segue-se o relaxamento lento até a linha de base. Êsse relaxamento poderá ser muito rápido se a preparação fôr lavada (Fig. 23). Êsse resultado indica evidentemente que o comportamento do músculo após a excitação é do tipo fásico.

Os dados referentes à relação dose-efeito, analisados estatìsticamente, mostram que as contrações são proporcionais à concentração da droga. Convém assinalar a ausência de variação da sensibilidade dêsse músculo durante tôdas as experiências.

No que se refere aos potencializadores, foi possivel verificar apenas que a Fisostigmina e a Prostigmina potenciali- 
zam a ação da $\mathrm{ACh}$, ainda que a dose potencializadora seja bem maior do que a usada para músculos de Vertebrados.

Dada a ação bloqueadora dos curares em relação à da $\mathbf{A C h}$, era de se esperar que a Succinilcolina também fôsse inibidora dêste éster. Tal não aconteceu; ao contrário, essa substância potencializou a $\mathrm{ACh}$ (Fig. 15). Mesmo nos Vertebrados, porém, segundo BOVET-NITTI (1959, p. 240) a Succinilcolina tem uma potencialidade colinérgica, agindo por despolarização da membrana.

A Fig. 16 mostra a ação inibidora da Atropina em relação à $\mathrm{ACh}$ o que condiz com o comportamento dos músculos lisos de Vertebrados. Por outro lado, êste músculo reage aos demais bloqueadores de $\mathrm{ACh}$ tal como os músculos fásicos estriados dos Vertebrados, i.é, o Benzoquinônio, a d-Tubocurarina e o Triiodo etilato de Galamina inibem parcial ou totalmente a ação da $\mathrm{ACh}$.

O mecanismo da ação dos curares no que se refere aos vertebrados já se acham em grande parte esclarecidos, mas, quanto aos invertebrados muito pouco se conhece, principalmente sôbre as reações dos músculos lisos aos leptocurares. $O$ fato de agirem no M.R.P. do mesmo modo em relação à ACh sugere que êste músculo possui propriedades dos músculos estriados dos Vertebrados.

Deve-se, ainda, assinalar que o M.R.P. é insensivel à Histamina, à Adrenalina, à Triptamina, e à Pilocarpina, não tendo estas substâncias nenhum feito sôbre a atividade da $\mathrm{ACh}$.

Quanto às outras substâncias, é de se pôr em relêvo a ação da Nicotina, evidenciada por uma forte contração do músculo, que permanece como contração sustentada por tempo muito maior que a da $\mathrm{ACh}$. A Nicotina e a $\mathrm{ACh}$, interreagem em determinadas condições, merecendo reparo, a ação repetida da Nicotina que leva a um bloquêio da atividade da ACh (Fig. 20). Êste fato já foi objeto de exame por TWAROG (1954, p. 141) que o registra ao estudar o músculo retrator anterior ao bisso. 
A explicação possível seria a de uma saturação dos receptores da ACh, pela Nicotina, saturação essa que se poderia dar paulatinamente à medida que fôssem aplicadas com maior frequência, as doses do alcalóide. Os resultados mostram mais uma vêz, propriedades dêsse músculo que o aproximam dos estriados de Vertebrados. A sensibilidade à Nicotina e a reação do músculo a essa droga indicam a ação nicotínica da ACh.

Deve-se notar que o comportamento do M.R.P. em relação à Serotonima.

O M.R.A.B. de M. edulis é sensível à Serotonina e mesmo permite a determinação da quantidade de Serotonina na relação de 1:10 ainda em presença de altas concentrações de Histamina, tendo sido, uma das preparações recomendadas para o ensáio biológico da Serotonina (GARATTINI \& VALZELLI, 1965, p. 21).

A êste propósito é digno de nota que várias estruturas dos moluscos como sejam, o coração de Venus mercenaria (PROSSER, 1940, p. 93; WELSH, 1954, p. 950) ; o coração isolado de Anodonta cygnea (BARNES 1955, p. 160); Helix pomatia (animal total - GRYGLEWSKI \& SUPNIEWSKI 1963, $\mu$ 53); o coração do próprio Mytilus perna (SAWAYA \& KHOURI 1965, p. 9), o de Anodontitis (DITADI 1964, p. 198) e outros, foram empregados em tais ensáios, tanto para a Serotonina como para a Acetilcolina e outras drogas.

No caso do M.R.P. a Serotonina isoladamente não determina reação na contração e nem no relaxamento, mas aplicando-se a Serotonina e logo a seguir a $\mathrm{ACh}$, o efeito desta é parcialmente bloqueado (Fig. 22). Infelizmente não me foi possível chegar a verificar a que concentração de Serotonina se poderia obter o bloqueio total. Esse comportamento se poderia explicar, admitindo-se uma inibição da ACh pela Serotonina de modo que esta, agindo sôbre o músculo, bloquearia os receptores da $\mathrm{ACh}$, impedindo, assim, esta de agir. Êste fato parece negar a existência de receptores da Serotonina no M.R.P. 
Para confirmar esta sipótese, sem dúvida, seriam necessárias novas experiências, em melhores condições, para se chegar talvez a uma conclusão.

Ainda sôbre o efeito da Serotonina, em estruturas de Moluscos, convém lembrar que essa substância atúa de modo surpreendente na musculatura do estômago de Helix pomatia que é extremamente sensível a êste derivado da Triptamina, pois se contráe na concentração $5 \times 10^{-13}$ (GRYGLEWSKI \& SUPNIEWSKI 1963, p. 53).

Deve-se assinalar que não poucos autores consideram o efeito da Serotonina como específico para os músculos lisos e não relacionado com o efeito da $\mathrm{ACh}$ ou da Histamina. $\mathrm{O}$ grupo de GADDUM (1965, p. 88) propôs o têrmo «receptores de Triptamina» para classificar os receptores do músculo liso sensíveis à Serotonina. Esta é uma questão ainda discutida, na qual não desejo interferir ainda, por falta de melhores elementos.

Como disse, o M.R.A.B. foi de todos os músculos de Mytilus o mais pesquisado, não só por ser o mais fàcilmente acessível como também, e principalmente, por ser o músculo que apresenta o curioso fenômeno de se contrair de acôrdo com o tipo de excitação. Assim, estimulado pela corrente direta (WINTON 1937, p. 495; TWAROG 1954, p. 41 e HOYLE \& LOWY 1956, p. 298) ou pela Acetilcolina (TWAROG 1.c., p. 41; HOYLE \& LOWY 1.c., p. 305; CAMBRIDGE, HOLGATE \& SHARP 1959, p. 453) reage com uma contração tônica, do tipo da contração sustentada de longa duração, ao passo que, estimulado com corrente alternada se comporta como músculo fásico.

Em Mytilus perna, o músculo retrator anterior do bisso é sensivel à $\mathrm{ACh}$ na concentração limiar de $2 \times 10^{-8}$. Esta droga, após excitar o músculo, provoca a contração com uma certa latência. $O$ período latente, varia de 10 a 20 segundos, na dependência da concentração da dose de ACh e numa relação inversa entre latência e concentração, i.é, com doses limiares, o período de latência é maior (Fig. 24). A contração 
provocada pela $\mathrm{ACh}$ é sustentada mesmo depois da remoção dêsse agente despolarizante. Em alguns testes preliminares, após duas horas, o músculo tinha atingido só metade do seu relaxamento. Êste comportamento, demonstrado pelos resultados referidos na parte experimental, assinalam ser o M.R.A.B. um músculo que se comporta preponderantemente de maneira tônica. Ainda mais, pelo que se conhece, nenhum estudo dose-efeito foi feito, relacionando concentração de ACh e respostas dos músculos de Mytilus. Em todos os trabalhos em que a $\mathrm{ACh}$ foi utilizada, citou-se sempre a dose aplicada $\left(1 \times 10^{-6}\right.$ - TWAROG 1954 , p. $148 ; 1 \times 10^{-7}$ - HOYLE \& LOWY 1956, p. 305) e, no máximo a limiar $\left(2 \times 10^{-7}-\right.$ CAMBRIDGE, HOLGATE \& SHARP 1959, p. 453). Mesmo com o emprêgo da $\mathrm{ACh}$ em várias concentrações, não foram elas escolhidas de tal modo a permitir retificação da curva dose-efeito e a análise da linha de regressão.

Esta análise no M.R.A.B. de M. perna mostrou que êste músculo responde à $\mathrm{ACh}$ seguindo uma linha reta com insignificante desvio da linearidade. Nota-se que a variação das respostas a uma certa concentração é muito pequena como se vê na Fig. 26.

O meu principal interêsse ao abordar a fisiologia e a farmacologia dos músculos de Mytilus não foi tanto discutir o chamado paradoxo apresentado por êsse músculo e bem relatado por HOYLE \& LOWY (1956, p. 295) e HOYLE (1957, p. 79), mas principalmente verificar as bases fisiológicas e farmacológicas dos músculos já anteriormente referidos, de modo a conhecer melhor a fisiologia de cada um dêles para uma possível interpretação do comportamento de Mytilus.

Dos resultados relativos aos potencializadores da $\mathrm{ACh}$ revelou-se que a potencialização é mais intensa pela Fisostigmia na concentração de $5 \times 10^{-8}$.

A Succinilcolina, como se viu, segundo BOVET-NITTI (1959, p. 240) age por despolarização, competindo com a $\mathrm{ACh}$, levando o músculo a se contrair ou por inibição, impedindo a liberação de $\mathrm{ACh}$. Isto, porém, é referido para os músculos 
estriados dos Vertebrados ao nível da placa motôra. Deve-se notar que o M.R.A.B. de M. perna não reagiu à Succinilcolina na concentração de $1 \times 10^{-5}$, ao passo que os demais inibidores da ACh testados atuaram, se bem que em diferentes graus de intensidade. Dentre êles, o mais potente foi o Mitolon, porém o músculo se liberta ràpidamente do seu efeito; segue-se a Atropina, cuja ação inibidora persiste por mais tempo. A d-Tubocurarina, teve efeito inibidor mais acentuado do que o Triiodo etilato de Galamina, que é, como se șabe, um curare do tipo intermediário entre os lepto- e os paquicurares. A ação do Triiodo etilato de Galamina está mais próxima à do último grupo, o que se comprovou à vista das reações do M.R.A.B. em relação à Succinilcolina, Triiodo etilato de Galamina e d-Tubocurarina, pois o músculo se mostrou mais sensível aos paquicurares (d-Tubocurarina) e insensível aos leptocurares (Succinilcolina). Êstes resultados mostram uma relação entre a estrutura molecular dêsses curares e a reação que provocam no M.R.A.B.

Dentre as drogas que atuam sôbre estruturas colinérgicas procurei estudar as reações dêsse músculo à Pilocarpina, que geralmente tem forte ação muscarínica, e ao Mecolil, o qual, embora com pequena ação muscarínica, não tem pràticamente ação nicotínica. O M.R.A.B. não reagiu diretamente nem à Pilocarpina e nem ao Mecolil. Êste concorreu para um leve aumento da contração provocada pela $\mathrm{ACh}$. Ëste resultado conduziria talvez a uma indicação de que os receptores do M.R.A.B. aceitam, indiferentemente a $\mathrm{ACh}$ e o Mecolil. A interferência dos dois agentes sôbre o músculo, resultaria, numa somação de efeitos.

A Serotonina tem ação relaxante sôbre o M.R.A.B. Os resultados experimentais com o músculo recém dissecado, tratado por Serotonina mostram que o mesmo não apresenta ̀̀ ACh uma contração sustentada durante muito tempo.

Se o músculo já foi tratado pela $\mathrm{ACh}$ e está, portanto na fase de contração sustentada ou de lento relaxamento, a 5-Hydroxy-Triptamina atúa, relaxando-o imediatamente. 
Comparando os resultados de outras drogas com a ação da Serotonina sôbre o relaxamento dêsse músculo, evidencia-se o efeito relaxante desta última droga. Como se conhece, a Serotonina provoca êsse efeito no M.R.A.B. do M. edulis, em concentrações da ordem de 0.001-0.01 $\mu \mathrm{g}$ (ERSPAMER). 1963, D. 171).

A Adrenalina não modificou a curva de relaxamento no músculo contraído pela $\mathrm{ACh}$.

Por esta comparação se vê marcante e notável efeito da 5-HT. Adicionada na fase de lento relaxamento, êste imediatamente se completa e o músculo, na resposta seguinte à $\mathrm{ACh}$, torna-se tipicamente fásico, apresentando contração rápida, sem sustenção alguma; ao contrário, atingindo o máximo de contração aos 30 segundos, inicia-se o relaxamento, que se completa instantaneamente após lavagem da preparação (Fig. 25).

Dentre os inúmeros trabalhos com os músculos retratores do bisso, sòmente em alguns, a preparação utilizada, foi também o M.R.P.B., na tentativa de se elucidar o mecanismo da manutenção de tensão prolongada de modo sui generis por êsses músculos. A razão dêle ter sido menos estudado que 0 M.R.A.B., quero crêr que reside no fato de ser mais difícil sua preparação. Tem o mesmo comportamento que o M.R.A.B., que é muito mais adequado às preparações isoladas. Êste fato levou TWAROG (1954, p. 141) a dizer que o M.R.A.B. significa para o estudo dos aspectos fisiológicos dos músculos lisos o que o sartorius de rã é para o estudo do músculo estriado.

No que se refere ao M.R.P.B., a preparação mostrou-se sensível à $\mathrm{ACh}$ com um limiar próximo ao encontrado para o M.R.A.B. ou seja, $5 \times 10^{--8}$.

O estudo dose-efeito da ACh sôbre êsse músculo, também aquí apresentado pela primeira vez, evidencia uma proporcionalidade das amplitudes de contração em relação às concentrações da ACh. A análise estatística mostra que a 
linha de regressão é significante, embora o desvio da linearidade tenha sido significante.

Também o M.R.P.B. de $M$. perna contraiu-se sustentando a contração provocada pela $\mathrm{ACh}$, portanto prepondera nêste músculo a fase tônica.

Os resultados da análise estatística levam a admitir que o M.R.P.B. é, dentre os músculos utilizados, o que seria menos adequado para o estudo em preparações isoladas. Sòmente êste músculo apresentou desvio da linearidade significativo, ao nível dos $5 \%$ de probabilidade.

Assim, para um estudo mais minucioso da fisiologia e da farmacologia do músculo de Mytilus é necessário considerar separadamente o M.R.A.B. e o M.R.P.B.

Como já assinalado, as dificuldades encontradas no uso do M.R.P.B. não possibilitaram uma investigação completa de suas reações ao tratamento por agentes farmacológicos. Além do mais, as primeiras tentativas de potencializar o efeito da ACh nessas preparações, mostraram resultados semelhantes aos do M.R.A.B. de M. perna.

Convém aquí salientar apenas a dificuldade da ação potencializadora da Prostigmina nêstes músculos do bisso.

Quanto aos inibidores da $\mathrm{ACh}$ o M.R.A.B. se mostrou mais sensível ao Mitolon, e em escala decrescente, bem menos sensível à Atropina, à D-tubocurarina e ao Flaxedil.

Também o M.R.P.B. não reagiu ao tratamento pela Succinilcolina, não apresentando efeito inibidor e nem uma potencialização da ACh.

A Serotonina possui ação seletiva na abolição da resposta tônica, sem interferir na sensibilidade do músculo à $\mathrm{ACh}$ que age, aqui, provocando contrações fásicas. Durante a manutenção da contração, a Serotonina susta-a imeditamente, libertando o músculo que prontamente se relaxa.

Esboço de contração se registrou para o M.R.P.B. à adição de Bromo-L.S.D. que, ao que se sabe bloqueia a ação da Serotonina no coração de Venus mercenaria, ao passo que o L.S.D. o excita da mesma forma que a Serotonina, porém 
a ação do L.S.D. é mais duradoura (WELSH \& McCOY 1957, p. 348).

$\mathrm{O}$ músculo continuou reagindo da mesma forma à $\mathrm{ACh}$, apresentando, porém, depois de algum tempo, após a lavagem da preparação, contrações vigorosas, que culminavam com sustentação ao nível do relaxamento parcial, médio. Nas experiências realizadas, esta foi a única vez em que se obteve tal resultado. Não disponho de dados suficientes para a interpretação desta reação. HOYLE \& LOWY (1956, p. 302) assinalam contrações tônicas espontâneas ocasionais do M.R.A.B. de $M$. edulis quando, após contração fásica do músculo, induzidas por corrente alternada, volta a contrair-se parcialmente, mantendo o novo nível de contração tônica. Nas experiências aquí relatadas talvez isso mesmo tenha acontecido por efeito posterior ao tratamento pelo Bromo-L.S.D.

O M.R.P.B. reagiu bem à Nicotina, contraindo-se fortemente à adição de $2 \mu \mathrm{g}$ da droga concentração final ( $\left.2 \times 10^{-8}\right)$ - equivalente às doses sub-limiares de $\mathrm{ACh}$ para êsse músculo.

Resta agora assinalar, embora sumàriamente, as diferenças com os músculos de $\boldsymbol{M}$. edulis.

Como se viu, o M.R.P. de M. edulis não foi estudado sistemàticamente, e, por isso, os resultados conseguidos com o M.R.P. de M. perna parecem constituir a primeira contribuição real para o conhecimento da fisiologia dêste músculo nos Lamelibrânquios. Os dados existentes de ABBOT \& LOWY (1953, p. 50P) referem-se às propriedades mecânicas dos músculos em $\boldsymbol{M}$. edulis e assinalam diferenças na razão «twitch»/tétano para os músculos, retrator do pé $(1: 3)$, retrator anterior $(1: 8)$ e retrator posterior do bisso (1:14). Ainda, em respostas a estímulos elétricos, choques simples ou repetidos, ABBOT \& LOWY (1958a, p. 393), estudam a contração do músculo liso em moluscos, para analisar suas propriedades tônicas e verificaram que o M.R.P. de $M$. edulis se relaxa completamente depois de qualquer tipo de estimulação, além de apresentar maior rapidez na contração. 
Esses foram os únicos dados que encontrei na bibliografia disponível, referentes ao M.R.P. e que confirmam os resultados obtidos quanto ao seu comportamento diferir dos músculos do bisso, por se contrairem e relaxarem mais ràpidamente que êstes últimos, nunca apresentando a contração sustentada. Nêste particular, os meus resultados confirmam os acima citados.

Os músculos do bisso, por outro lado, vêm sendo estudados intensamente, destacando-se o uso do M.R.A.B., de modo especial pelo interessante fenômeno paradoxal, apontado por vários autores e agora reestudado por HOYLE \& LOWY (1956, p. 295), por HOYLE (1957, p. 79) e mais recentemente por RÜEGG \& WEBER (1963, p. 308; 1964, p. 537) por LOWY, MILLMAN \& HANSON (1964, p. 525).

Em resumo, êsse paradoxo reside no contrôle da tensão mostrado por êstes músculos, de estrutura simples, fibras lisas longas (FLETCHER 1937a, p. 234), com comportamento diverso na fase de relaxamento, quando estimulado pela corrente elétrica direta ou pela $\mathrm{ACh}$, e pela corrente elétrica induzida.

No primeiro caso, o relaxamento é lento e a contração do tipo tônica, e no segundo o relaxamento é rápido e a contração é fásica.

Os resultados das experiências realizadas por diversos autores com os retratores do bisso, de $\boldsymbol{M}$. edulis, os levaram a se dividirem em dois grupos para explicar êșse paradoxo: o primeiro, em que se encontra WINTON (1934) que atribue a manutenção da contração a um processo mecânico, ou seja, um entrave ou enganchamento dos elementos contráteis, com modificações da viscosidade, apoia a teoria do «catch mechanism» que traduzo, na falta de melhor têrmo, por «mecanismo de enganchamento». O segundo explica essas diferenças por um processo ativo, fisiológico do músculo, desde que HOYLE \& LOWY (1956, p. 296 e 305) registraram atividade elétrica do músculo, na fase de lento relaxamento, lançando, assim, a teoria do tétano. 
O problema do «catch mechanism» vem preocupando os fisiólogos đe longa data. Já von UEXKÜLL (1912, p. 305) tratou da contração tônica de músculos dos Lamelibrânquios, denominando êsse processo de «Sperrung» e que os inglêses traduziram por «catch mechanism».

Daí para cá, numerosos autores se preocuparam com essa questão. HOYLE (1957, p. 79) dá um resumo muito bom dêste assunto e propõe a sua interpretação que vem a ser a teoria do tétano, baseado no fato de o M.R.A.B., durante a contração tônica, mostrar atividade elétrica na fase de relaxamento.

Recentemente o assunto foi retomado, tendo LOWY, MILLMAN \& HANSON (1964, p. 525) apresentado numa «Discussão sôbre as bases físicas e químicas da contração muscular» uma série de considerações sôbre a estrutura e função dos músculos tônicos dos lamelibrânquios. Indicam na estrutura do M.R.A.B. de M. edulis a existência de filamentos finos de actina e grossos com grande quantidade de tropomiosina ligada à paramiosina. Com base nessa estrutura, comentam longamente a terceira hipótese com que se pretende explicar a contração tônica, i.é, a «linkage hypothesis». O sistema «tropomiosina-paramiosina e contração prolongada» foi objeto de uma apresentação, na referida «Discussão», por parte de RÜEGG (1964, p. 537) dos resultados que conseguiu com as experiências sôbre os filamentos de actomiosina artificialmente preparados pelo extrato, em glicerol, do M.R.A.B. e cujo relaxamento é inativado pelo Salirgan ou pela Tiureia. Aliás, êste autor já havia apresentado (1963, p. 308) os fundamentos de «linkage hypothesis» ao tratar do cíclo da contração e do tonus do M.R.A.B.

Ainda no que se refere à fisiologia do M.R.A.B. devem ser lembrados os resultados das experiências fisiológicas com estímulos elétricos ou drogas, que indicam, a existência de uma inervação complexa, não uniforme (HOYLE \& LOWY 1956, p. 308). Fortes evidências existem que levam os auto- 
res a afirmar a ocorrência de inervação dupla, ou seja, excitadora e inibidora. Esta já foi assinalada para músculos de moluscos em 1885 por PAVLOV (p. 6). FLETCHER (1937b, p. 416) verificou que estímulos elétricos aplicados diretamente, provocam relaxamento do músculo em contração tônica. NIEUWENHOVEN (1947) obteve o mesmo efeito com estimulação farádica fraca do gândio pedal; TWAROG (1954, p. 152,160 e 161) assinala que a 5-HT está presente. no M.R.A.B. e provoca relaxamento; e HOYLE \& LOWY (1956, p. 309) verificaram com estimulação do nervo «inibidor», parada da atividade elétrica, e que a Serotonina abole seletivamente a resposta tônica, permanecendo inalterável a resposta fásica.

Os pesquisadores filiados às duas correntes são concordes em afirmar que a inervação inibidora é mediada ou mimetizada pela 5-HT, responsável pelo término da contração mantida qualquer que seja o mecanismo atribuido à sua manutenção.

Comparando os resultados que obtive para o M.R.A.B. de $\boldsymbol{M}$. perna com os de $\boldsymbol{M}$. edulis relatados por outros pesquisadores, verifica-se que não há diferença quanto ao comportamento em relação à $\mathrm{ACh}$ e à Serotonina. Nos dois casos, o músculo mostrou-se sensível às drogas, e as diferenças de limiar encontradas podem ser atribuidas às condições experimentais, principalmente no que tange à temperatura. Para o M. perna, os dados foram obtidos entre $23-26^{\circ} \mathrm{C}$, ao passo que os de $\boldsymbol{M}$. edulis se referem a experiências realizadas a $10-16^{\circ} \mathrm{C}$. Apresenta-se aquí um outro problema de natureza ecológica, o qual, embora mereça atenção por sua importância, excede os limites dêste trabalho.

A presença de fibras colinérgicas foi assinalada por TWAROG (1954, p. 153) e CAMBRIDGE, HOLGATE \& SHARP (1959, p. 459) no M.R.A.B. com a técnica da colinesterase positiva, com $\mathrm{pH}$ 6,5. Infelizmente, não consegui ainda dados precisos sôbre o teôr de colinesterase nos vários pares de músculos de $\boldsymbol{M}$. perna, o que, ao meu ver, auxiliaria 
a interpretação dos resultados para a potencialização da $\mathrm{ACh}$ nêsses três músculos, bem como explicaria parcialmente as suas diferenças na velocidade da contração e do relaxamento.

Tanto no $M$. edulis (CAMBRIDGE, HOLGATE \& SHARP 1959, p. 459) como no M. perna a $\mathrm{ACh}$ foi potencializada pela Eserina (Fisostigmina) no M.R.A.B. (Fig. 28) e inibida pela Atropina que mostrou ser um bloqueador relativamente fraco tanto em $\boldsymbol{M}$. edulis (CAMBRIDGE, HOLGATE \& SHARP, l.c., p. 460) como em M. perna, se bem que de ação persistente (Fig. 30 e 35).

Apesar de outros autores afirmarem que o M.R.A.B. é sensivel ao Acetil $\beta$-metilcolina, que seria mais ativo que a $\mathrm{ACh}$ (CAMBRIDGE, HOLGATE \& SHARP, 1.c.) nos músculos de $M$. perna, esta substância não agiu, mas em alguns casos potencializou o efeito da $\mathrm{ACh}$.

A Nicotina atuou no M.R.P. de M. perna (Fig. 20) do mesmo modo assinalado por TWAROG (1959, p. 404) no M.R.A.B. de M. edulis.

Quanto aos agentes bloqueadores da ACh obtive os mesmos resultados com Mitolon, Atropina e D-tubocurarina. Segundo CAMBRIDGE, HOLGATE \& SHARP, 1.c. p. 460) o efeito bloqueador desta droga em relação à $\mathrm{ACh}$ não é análogo ao que ocorre no reto do sapo, sendo as respectivas razões de droga $1: 15$ no M.R.A.B. de M. edulis e $1: 3$ no reto abdominal. No M.R.A.B. de $\boldsymbol{M}$. perna a inibição de $30 \%$ da resposta à $\mathrm{ACh}$ pela D-tubocurarina foi obtida na razão de droga de 1:12,5. Essa inibição não parece estar relacionada, com o poder bloqueador dos gânglios, pela D-tubocurarina, nas preparações de mamíferos, confirmando assim a ausência de gânglios ou qualquer estrutura nervosa semelhante à placa motôra ou células nervosas dentro dêstes músculos (ABRAHAM \& MINKER 1957, p. 926) ; CAMBRIDGE, HOOLGATE \& SHARP, 1.c. 459 e outros).

O quadro geral que agora se apresenta é o de um lamelibrânquio, o Mytilus perna, com músculos, não estriados de fibras longas, que se comportam diferentemente. Para expli- 
car o comportamento dos mesmos talvez fôsse de grande valia um confronto com a ultraestrutura dos músculos do bisso, visto como a ausência, ou um teôr menor de tropomiosina no M.R.P., confirmaria a ação desta proteina. O sistema excitador seria colinérgico ativando os dois sistemas contráteis ou seja, o responsável pela resposta tônica, que teria grande quantidade de tropomiosina no seu duplo arranjo de filamentos, e o responsável pela resposta fásica, livre de tropomiosina.

A tropomiosina estaria associada ao mecanismo do enganchamento, sendo capaz de, mecanicamente, sem grande dispêndio de energia, sustentar a contração por muito tempo. $O$ desentrave dessas ligações mecânicas, provocaria o relaxamento imediato do músculo. Isto se daria pela estimulação do sistema inibidor, constituido por fibras nervosas mediadas pela 5-HT.

Quando o mecanismo inibidor entra em ação, êste só atuaria sôbre o sistema contrátil tônico e portanto o músculo continuaria a contrair-se, porém, apenas pelo sistema fásico, mediado, ainda, por terminações nervosas colinérgicas.

O fato do M.R.P., do M.R.A.B. e do M.R.P.B. reagirem à $\mathrm{ACh}$ e aos inibidores já mecionados, indicaria que os três músculos possuem fibras nervosas colinérgicas. A $\mathbf{A C h}$ agiria no M.R.P. sôbre um único sistema contrátil, provocando reações rápidas seguidas sempre de rápido relaxamento. Nos músculos do bisso, a ACh ativaria dois sistemas contráteis, um de comportamento semelhante ao do M.R.P. e outro capaz de contrair-se ràpidamente e sustentar a contração em vários níveis, durante muitas horas. Apenas êste último sistema receberia fibras inibidoras cuja mediação se daria pela Serotonina. Só êsses músculos teriam «receptores de triptamina». A Serotonina agiria destravando o enganchamento e provocando, portanto, relaxamento imediato do músculo. Entretanto, como age e onde age a Serotonina, nêsses músculos, é uma questão ainda não resolvida.

Esta hipótese parece reforçada quando se estuda o comportamento do animal no seu habitat. 
Finalmente, um dos objetivos dêste trabalho é também o de verificar em que extensão a musculatura concorre para o comportamento do animal. Como foi dito, no início, os mexilhões, pelo menos os do tipo aquí estudado, vivem aderentes às rochas, principalmente em zonas do mar batidas pelas ondas, portanto, em regiões bem oxigenadas e frequentemente expostas ao ar atmosférico durante a baixa-mar.

Para manter essa posição haveria necessidade de um mecanismo capaz de se opôr ao embate das ondas. A aderência ao substrato, é sabido, dá-se à custa de filamentos secretados pela glândula do bisso e que se gelificam em contáto com a água do mar. Nêste complexo mecanismo entrariam em ação, de maneira preponderante os músculos do pé e os do bisso. O pé é usado na locomoção do animal, pois é o órgão que orienta a fixação de um novo filamento bissal. A glândula do bisso continúa pelo pé através de sua goteira mediana ventral por onde a secreção é lançada, quando o pé se alonga e se apoia num determinado ponto do substrato. Depois de algum tempo, o pé retrae-se ràpidamente, e pode-se observar o novo filamento solidificado. $\bar{A}$ medida que novos filamentos são fabricados, os músculos do bisso começam a se contrair gradativamente, vencendo, com contrações golpeadas vigorosas, a resistência dos velhos filamentos endurecidos, arrancando-os do substrato. Uma ação coordenada dos três pares de músculos do bisso, desloca o animal em direção aos novos filamentos fabricados.

A orientação e a disposição dos fios que constituem o bisso é surpreendente e deixam perceber que o animal se encontra perfeitamente sustentado por estas estruturas.

Então, o pé colaboraria não só na locomoção do animal, dando nova orientação aos filamentos do bisso como também concorreria para a reposição dos filamentos velhos perdidos. Seria o responsável pela forma e pela direção dos fios que se apresentam com certo grau de elasticidade e bastante resistentes. 
A musculatura do bisso, se bem que independente da musculatura do pé, agiria coordenadamente com os seus músculos retratores promovendo o deslocamento do animal na direção antero-posterior, dorso-ventral e latero-lateral. A grande resistência ao impacto das ondas se deveria também à contração dêsses músculos, pelo deslocamento do animal, principalmente no sentido dorso-ventral, aproximando-o ainda mais do substrato e mantendo-o nessa posição por sustentação da rápida contração.

A contração dêsses músculos auxiliaria também a função do músculo adutor que é a de aduzir as valvas exercendo uma fôrça tal que deve ser equivalente à resistência, oferecida pelo ligamento elástico, ao fechamento da concha. Dêste perfeito fechamento depende a sobrevivência do animal quando exposto ao ar ou quando atacado por seus predadores naturais, dentre êles a estrela do mar. Aliás, nêste particular é de se lembrar que o mecanismo de abertura das valvas é um problema ainda à espera de solução. Já em 1885 PAVLOV (p. 6) o havia abordado e recentemente BURNETT (1961, p. 13) ainda discute as teorias sôbre o mecanismo de abertura das valvas pelas estrelas do mar, que são os principais inimigos dos Mytilus.

Torna-se assim evidente que as reações de todos êsses músculos analisadas em preparações isoladas, concordam com a função que devem exercer no animal em seu habitat natural.

Estas considerações finais resultaram das observações dos mexilhões de nossas práias, nos aquários do Departamento de Fisiologia Geral e Animal e do Instituto de Biologia Marinha e no local de captura.

Encerrando o presente trabalho relembraria aquí os dizeres de TWAROG (1949, p. 38) nas considerações gerais sôbre os estudos realizados com a musculatura de $\boldsymbol{M}$. edulis: «Possivelmente a questão mais crucial envolvida nêstes estudos seria a da função do M.R.A.B. em condições fisiológicas naturais». Estenderiamos essa asserção aos demais músculos de $M$. perna. 
7.

\section{O N C LUSÕ E}

1. Os músculos de Mytilus perna e os de Mytilus edulis apresentam disposições anatômicas diferentes. Em $\boldsymbol{M}$. perna é ausente o músculo adutor anterior; o músculo retrator do pé é idêntico ao de $\boldsymbol{M}$. edulis mas a sua inserção na face profunda da concha de $\boldsymbol{M}$. perna é mais mediana dorsal. O músculo retrator anterior do bisso é idêntico em ambas as espécies; o músculo retrator posterior do bisso apresenta na face profunda da concha uma única zona de inserção em $M$. perna, ao passo que em $\boldsymbol{M}$. edulis mostra vários pontos separados uns dos outros.

2. Os músculos retratores do pé e os do bisso são sensíveis à Acetilcolina (limiar respectivamente de $1 \times 10^{-8}$ (M.R.P.), $2 \times 10^{-8}$ (M.R.A.B.) e $5 \times 10^{-8}$ (M.R.P.B.) cuja ação é potencializada pela Fisostigmina.

3. Os músculos retratores anterior e posterior do bisso, estimulados pela $\mathrm{ACh}$ reagem com uma contração rápida mas o relaxamento é prolongado.

4. A Nicotina, o Mitolon, a Atropina, a D-tubocurarina e o Flaxedil mostraram ação bloqueadora a da ACh. Todos, com exceção da Nicotina, não têm ação direta sôbce os referidos músculos de $\boldsymbol{M}$. perna. A Nicotina provoca contração no M.R.P. e no M.R.A.B. e, em estimulação repetida, deprime a ação da $\mathrm{ACh}$ no M.R.P.

5. A Succinilcolina, no músculo retrator do pé não bloqueou a ação da $\mathrm{ACh}$, como os demais curares, mas, ao contrário, mostrou uma ação potencializadora da ACh. Êste fato singular é discutido no presente trabalho.

6. A Sucinilcolina não se mostrou ativa nos músculos retratores anterior e posterior do bisso.

7. A Serotonina não excita os músculos mencionados no item 5 . 
8. A Serotonina inibe, parcialmente, a ação da ACh no músculo retrator do pé.

9. A Serotonina, nos músculos retratores anterior e posterior do bisso provoca imediato relaxamento da contração tônica.

10. Prèviamente tratados pela Serotononia, os músculos retratores anterior e posterior do bisso não mostram nenhuma reação, mas adicionando-se a seguir a $\mathrm{ACh}$, as respostas são fásicas e não tônicas. 


\section{B I B L I O G R A F I A}

ABBOT, B. C. \& LOWY, J. - 1953 - Mechanical properties of Mytilus muscle. J. Physiol., 120: 50P

ABBOT, B. C. \& LOWY, J. - 1958 - Contraction in molluscan smooth muscle. Ibidem 141: 385-397.

ABRAHAM, A. \& MINKER, E. - 1957 - Innervation of the lamellibranch muscle. Nature, London, 180: 925-926.

BARNES, Gordon E. - 1955 - The Behaviour of Anodonta cygea L., and its Neurophysiological Basis. - J. Exp. Biol., 32: 158-174.

BOUTAN, L. - 1900 - La Moule Comestible. Zoologie DescriptiveInvertébrés, 2: 457-508.

BOVET, D. - 1959 - Les curares à brève durée d'action em: BOVETNITTI, F. \& MARINI-BETTÒLO, G. B. - Curare and Curare-Like Agents. Elsevier Publ. Co. New York, XI+478 pp.

BURNETT, A. L. - 1961 - Enigma of an Echinoderm. Nat. Hist. 70(9): 10-19.

CAMBRIDGE, G. W. \& HOLGATE, J. A. - 1955 - A Method for the identification of 5-hydroxytryptamine. J. Physiol., 130: $22 \mathrm{P}$.

CAMBRIDGE, G. W., HOLGATE, J. A. \& SHARP, J. A. - 1959 - A pharmacological analysis of the contractile mechanism of Mytilus muscle. Ibidem, 148: 451-464.

DITADI, A. S. F. - 1964 - Effects of Acetylcholine on the Heart of a Fresh-Water Mussel. Rev. Brasil. Biol., 24(2): 197-221.

EGGLETON, M. G. - 1934 - A physiological study of phosphagen in plain muscle. J. Physiol., 82: 79-87.

EICHNA, L. W. - 1962 - Proceedings of a Symposium on Vascular Smooth Muscle. Physiol. Rev. 42, suppl. 5: V+365 pp.

ERSPAMER, V. - 1963 - 5-Hydroxytryptamine - em: von EULER, V. S. \& HELLER, H. - Comparative Endocrinology, 2. Tissue Hormones, XI +282 pp. Acad. Press. New York.

FISCHER, E. - 1944 - Vertebrate smooth muscle. Physiol. Rev. 24: 467-490.

FLETCHER, C. M. - 1937a - Action potentials recorted from unstriated muscle of simple structure. J. Physiol., 90: 233-253.

FLETCHER, C. M. $-1937 \mathrm{~b}-$ Excitation of the action of a molluscan unstriated muscle. Ibidem, 90: 415-428.

FLORKIN, M. \& HAROLD, F. B. - 1934 - Sur la teneur en proteins du sang et du liquide coelomique des invertébrés. Arch. Internat. Physiol., 38(4): 353-364. 
GADDUM, J. H. \& GIARMAN, N. J. - 1956 - Preliminary studies on the Biosynthesis of 5-Hydroxytryptamine. British J. Pharmacol., 11: 88-92.

GARATTINI, S. \& VALZELLI, L. - 1963 - Serotonin. X+393 pp. Elsevier Publ. Co. New York.

GLAISTER, D. \& KERLY, M. - 1936 - The oxygen consumption and carbohydrate metabolism of the retractor muscle of the foot of Mytilus edulis. J. Physiol., 87: 56-66.

GRYGLEWSKI, R. \& SUPNIEWSKI, J. - Bull. Acad. PoI. Sci., 11(1963): 53, apud GARATTINI, S. \& VALZELLI, L. - "Serotonin", $X+392$ pp. EIsevier Publ. Co. New York, 1963.

HOYLE, G. - 1957 - Comparative Physiology of the Nervous Control of Muscular Contraction. Cambridge Monogr. Exp. Biol., 7(8): 147 pp. Cambridge Univ. Press.

HOYLE, G. \& LOWY, J. - 1956 - The paradox of Mytilus muscle. A new interpretation. J. Exp. Biol., 33: 295-311.

KLAPPENBACK, M. A. - 1965 - Lista preliminar de los Mytilidae Brasileños en claves para su determinacion y notas sobre su distribuición. An. Acad. Bras. Cien., 37 (Suplemento): 326-352, 2 t. Rio de Janeiro.

LOWY, J., MILLMAN, B. M. \& HANSON, J. - 1964 - Structure and function in smooth tonic muscles of lamellibranch-molluscs. Proc. Roy. Soc. B., 160: 525-536.

MORRETES, F. L. - 1949 - Catálogo dos Moluscos do Brasil. Arq. Museu Paranaense, 7: 5-216. Curitiba.

NIEUWENHOVEN, L. M. von - 1947 - An Investigation into the structure and function of the anterior byssal retractor of Mytilus edulis L. - Rijksuniversiteitte Utrecht (Doctoral dissertation), apud TWAROG, 1949: 57.

PAVLOV, I. P. - 1885 - Wie die muschel ihre schale offnet Pfluger's Arch., 37: 6-31, apud TWAROG, B. M. - 1949: 23.

PROSSER, C. L. - 1940 - Acetylcholine and nervous inhibition in the heart of Venus mercenaria. Biol. Bull., 78: 92-214.

RUUEGG, J. C. - 1964 - Tropomyosin-paramyosin system and prolonged contraction in a molluscan smooth muscle. Proc. Roy. Soc. London, Ser. B, 160: 536-542.

RUEGG, J. C. \& WEBER, H. H. - 1963 - Kontrakzyklus und spertonus em: CORI, C. F., FOGLIA, V. G., LELOIR, L. F. \& OCHOA, S. Perspectives in Biology, XVII +557 - Elsevier Publ. Co. New York.

SAWAYA, P. \& KHOURI, J. - 1965 - The action of acetylcholine on the isolated heart of Mytilus perna. Bol. Fac. Fil. Ci. Letr. Univ. S. Paulo, Zool. 25: 5-12, São Paulo.

TWAROG, B. M. - 1949 - Tonic shortening in invertebrate smooth muscle with special reference to the anterior retractor of the bys- 
sus of Mytilus edulis L. - Thesis for the Degree of Master of Science (não publ.) 74 pp. - Tufts College.

TWAROG, B. M. - 1954 - Responses of a molluscan smooth muscle to acetylcholine and 5-hydroxytryptamine. J. Cell. Comp. Physiol. 44: 141-164.

TWAROG, B. M. - 1959 - The pharmacology of a molluscan smooth muscle. Brit. J. Pharmacol., 14: 404-407.

VON UEXKÜLL, J. - 1912 - Studien über den tonus. VI. Die Pilgermuskel. Z. Biol., 58: 305-332, apud JEWELL 1959: 154.

WELSH, J. H. - 1954 - Marine invertebrate preparation useful in the bioassay of acetylcholine and 5-hydroxytryptamine. Nature, London 173: 955-956.

WELSH, J. H. \& McCOY, A. C. - 1957 - Actions of d-Lysergic Acid diethylamida and its 2-bromo derivative on heart of Venus mercenaria. Science, 125: 348.

WHITE, K. M. - 1937 - Mytilus. Liverpool Memoirs Biological Committee, VII $+117,10$ t. Liverpool.

WINTON, F. R. - 1934 - The effects of frequency of alternating and intermittent direct current stimulation on isolated plain muscle (foot retractor Mytilus). J. Physiol., 82: 1-2 P.

WINTON, F. R. - 1937 - The changes in viscosity of an unstriated muscle (Mytilus edulis) during and after stimulation with alternating, interrupted and uninterrupted direct currents. J. Physiol., 88: 492-511. 